NBER WORKING PAPER SERIES

TIME DISCOUNTING AND ECONOMIC DECISION-MAKING AMONG THE ELDERLY

\author{
David Huffman \\ Raimond Maurer \\ Olivia S. Mitchell \\ Working Paper 22438 \\ http://www.nber.org/papers/w22438 \\ NATIONAL BUREAU OF ECONOMIC RESEARCH \\ 1050 Massachusetts Avenue \\ Cambridge, MA 02138 \\ July 2016
}

The research reported herein was performed pursuant to a grant from the U.S. Social Security Administration (SSA) funded as part of the Michigan Retirement Research Center. The authors also acknowledge support from the Pension Research Council/Boettner Center at the Wharton School of the University of Pennsylvania. They have also benefited from expert programming assistance of Yong Yu. Mitchell is a Trustee of the Wells Fargo Advantage Funds and has received research support from TIAA. This is part of the NBER Program on the Economics of Aging. Opinions and conclusions expressed herein are solely those of the authors and do not represent the opinions or policy of the SSA, any other agency of the Federal Government, the National Bureau of Economic Research, or any institution with which the authors are affiliated.

At least one co-author has disclosed a financial relationship of potential relevance for this research. Further information is available online at http://www.nber.org/papers/w22438.ack

NBER working papers are circulated for discussion and comment purposes. They have not been peer-reviewed or been subject to the review by the NBER Board of Directors that accompanies official NBER publications.

(C) 2016 by David Huffman, Raimond Maurer, and Olivia S. Mitchell. All rights reserved. Short sections of text, not to exceed two paragraphs, may be quoted without explicit permission provided that full credit, including $\odot$ notice, is given to the source. 
Time Discounting and Economic Decision-making Among the Elderly

David Huffman, Raimond Maurer, and Olivia S. Mitchell

NBER Working Paper No. 22438

July 2016

JEL No. D01,D03,D12,D14,E21,G11,I12,J26

\begin{abstract}
$\underline{\text { ABSTRACT }}$
This paper evaluates the extent of heterogeneity in time discounting among elderly Americans, as well as its role in explaining older peoples' key behaviors. We first show how older Americans evaluate simple (hypothetical) intertemporal choices in which payments now are compared with payments in the future. This adds to the literature on time horizon experiments by focusing on a nationally representative sample of persons age 70+. Using the indicators derived from this experiment, we show how differences in discounting patterns are associated with characteristics of particular importance in elderly populations, such as serious health and mental conditions. We then relate our discounting measure to key outcome variables including wealth, the timing of retirement, investments in health, and decisions about end of life care.
\end{abstract}

David Huffman

Economics Department

University of Pittsburgh

230 S. Bouquet St.

Pittsburgh, PA 15260

huffmand@pitt.edu

Raimond Maurer

Goethe University

Finance Department

Grüneburgplatz 1 (Uni-PF. H 23)

60323 Frankfurt am Main

Germany

maurer@finance.uni-frankfurt.de
Olivia S. Mitchell

University of Pennsylvania

The Wharton School

3620 Locust Walk, St 3000 SH-DH

Philadelphia, PA 19104-6302

and NBER

mitchelo@wharton.upenn.edu 


\title{
Time Discounting and Economic Decision-making Among the Elderly
}

\author{
David Huffman, Raimond Maurer, and Olivia S. Mitchell
}

Many economic and psychological studies have sought to explore how people make intertemporal decisions, but most previous research on impatience and its impact on economic and other outcomes has focused mainly on younger individuals (c.f., Burks et al. 2009; Chabris et al. 2008; Schreiber and Weber 2015; Sutter et al. 2013). Yet understanding how older individuals make decisions with intertemporal dimensions is of importance, inasmuch this is when many people make critically consequential financial decisions that affect the remainder of their lives. Examples include how much to save and spend, when to work versus claim Social Security benefits, whether and how much to invest in health and health insurance, whether to sell one's home and move, and many other factors central to retirement well-being.

There is also little known about the extent of heterogeneity in discount rates amount the elderly, and how such diversity might relate to personal characteristics. If time discounting varies systematically with demographic or cultural characteristics, this could have important implications for how economic outcomes vary for the elderly within society. Moreover, discounting could potentially change in old age, something that can only be studied in with data on elderly individuals. Aging involves reduced life expectancy, and lower probability of survival could potentially affect discounting of the future. Empirical evidence on whether and how life expectancy affects discounting, however, is scarce. ${ }^{1}$ Some aspects of cognitive functioning also become increasingly

\footnotetext{
${ }^{1}$ One exception is Oster et al. (2013), who show that individuals who are diagnosed with Huntington's disease at an early age make decisions consistent with greater discounting of the future. Sunde and Dohmen (forthcoming) have a nice recent review of preferences and aging, but they focus mainly on risk attitudes and not time preferences as we do here.
} 
difficult at older ages, in the form of dementia, but little is known about how this might affect intertemporal decision-making. For all of these reasons, it is of interest to delve into questions about the determinants of time discounting among the older population.

In this paper we present and analyze time discounting metrics measured in a representative sample of individuals age 70+. To this end, we use a purpose-built survey module we devised for the 2014 Health and Retirement Study (HRS) to examine the levels of and heterogeneity in time discounting among the elderly, and we study how this heterogeneity varies with personal characteristics. Moreover, we leverage the rich information about retirement, wealth accumulation, and health behaviors reported in the HRS to evaluate how and whether such heterogeneity helps explain differences in important economic behaviors across older individuals.

To preview results on heterogeneity and determinants, we show that the mean (median) value of the implied Internal Rate of Return (IRR) used by our older population to discount future payments is $0.54(0.58)$, with a standard deviation of $0.35 .^{2}$ Our IRR measures rise with age: thus a 15-year increase in age from 70 to 85 would be associated with about a standard deviation higher IRR. This result is robust to a variety of controls. We also show that Whites and the better-educated have lower IRRs. Serious health conditions, which imply reduced life expectancy, are associated with 11-30 percent higher IRRs. Cognition scores are not statistically associated with our impatience measures, controlling for education. An indicator for dementia, however, is associated with significantly higher IRRs.

When we relate our impatience measures to outcomes of interest using multiple regression models, several interesting results emerge. Net wealth is significantly lower for the least patient, probably indicating that the least patient save less and therefore arrive at old age with fewer assets.

\footnotetext{
${ }^{2}$ The IRR is the interest rate which sets equal the net present value of the future money amount and the money amount offered today.
} 
We also find that the impatient are much less likely to engage in healthy behaviors and to have made provision for end of life challenges. And finally, our analysis shows that Social Security claiming ages are not significantly related to the IRRs. We check robustness of the results to using an Impatience Index, which combines the IRR measure with a more subjective measure of impatience, and reach similar conclusions.

The next section offers a brief literature review. Next we outline our methodology, and the subsequent section provides descriptive statistics regarding the mean and dispersion of discounting among the elderly. In a final analytic section we review the association between several economic and health outcomes, and the measured discount rates we derive. A final section concludes.

\section{Background}

Economic theory holds that time discounting plays a crucial role in decision-making about inter-temporal tradeoffs. Thus over the life cycle, people must decide to consume less than their incomes when young and save and accumulate retirement assets, which they can then draw down to support old-age consumption. Nevertheless, everyone is not homogeneous. That is, those who discount the future more will place a higher value on current versus future consumption, which in turn will prompt them to save less and possibly run out of money in old age. Similarly, someone who discounts the future very heavily might claim Social Security benefits earlier, thus committing himself to lower old-age payments the rest of his life. And people who downweight the future can also make decisions about their own health, insurance, and other financial products, that may expose them to greater risks in old age.

Accordingly, we seek to determine the extent of time discounting among the elderly. Additionally we investigate whether such preferences can help explain heterogeneity in a wide 
range of decisions, including how long to work, whether to invest in one's own health, whether to purchase long-term care or life insurance, and what provisions to make regarding the end of one's life. Extreme levels of impatience may also be an indicator of self-control problems, in the sense of present-biased preferences (Rabin, 2002), so these might help predict preference reversals, for example individuals stopping work earlier than they had previously planned.

The present research therefore provides evidence on time discounting patterns among Americans age $70+$. With our survey, we also examine the cross-sectional association between time discounting and respondent characteristics, to explore population heterogeneity in impatience. To the extent that time individuals' attitudes toward time discounting are quite persistent over time, the measures of discounting that we elicit among older respondents may also be useful for explaining decisions made earlier in life. These include, for example, saving decisions resulting in more or less wealth in retirement. ${ }^{3}$

\section{Methods}

We have designed and implemented a survey module in the 2014 HRS to elicit time discounting among older adults. Specifically, we gave respondents over the age of 70 who were randomly selected to respond to this module a list of money choices where they considered receiving different payments at different points in time. The decision in the inter-temporal choice exercise was between " $\$ 100$ today" and some larger amount $\$ Y$ that would be received 12 months in the future (see Online Appendix A for the precise wording of the module).

Everyone taking the survey module first received a choice between a hypothetical payment of $\$ 100$ today versus a delayed payment of $\$ 154$ twelve months from today. If the respondent

\footnotetext{
${ }^{3}$ Meier and Sprenger (2015) report stability in peoples' attitudes toward time discounting over a time span of two years, but Dohmen et al. (2010) report some fluidity over the life cycle.
} 
responded that he preferred the later payment, he was shown a smaller delayed amount. If, however, the respondent favored the early payment, he was shown a larger delayed amount. Several such choices were provided until each respondent had indicated the value of Y (or equivalently, the implied annual rate of return) to which he was indifferent, when comparing receiving $\$ 100$ now versus waiting 12 months. In this way, we obtained an indicator of each respondent's implied internal rate of return. ${ }^{4}$

Our values in the choice exercise were chosen to match the magnitudes of rewards used in typical intertemporal choice experiments which are the gold standard for measuring time discounting. ${ }^{5}$ Falk et al. (2014) showed that the survey measure we use is a strong and significant predictor of time discounting in such choice experiments. ${ }^{6}$ Furthermore, Falk et al. (2015) found that the survey discounting measure they used predicted important outcomes such as savings and human capital accumulation in young population samples around the world. That evidence provides confidence that our survey measure does capture a trait that determines behavior under real stakes, despite the hypothetical payments and particular parameter values. ${ }^{7}$

Our HRS survey module also asked each respondent questions about his self-reported Future Oriented Score. This survey measure was also found by Falk et al. (2015) to correlate with behavior in incentivized intertemporal choice experiments, and add explanatory power when combined with the choice exercise into a single impatience index. Accordingly, we check

\footnotetext{
${ }^{4}$ See Online Appendix B for detail on the computation method.

${ }^{5}$ See Harrison et al. (2002) for a seminal paper on using choice experiments to measure individual discount rates in a representative sample. The experiments measure time discounting under a set of assumptions. One key assumption required for the experiments to provide an index of impatience is that individuals treat the monetary rewards like consumption opportunities.

${ }^{6}$ Falk et al. (2014) had subjects participate in incentivized intertemporal choice experiments and also answer a battery of different survey questions about time discounting. The survey measure we use is based on one of the best predictors of choices in those incentivized experiments (a measure that is part of the Falk et al. Preference Survey Module).

${ }^{7}$ While the magnitudes of monetary payments used in the measure are small relative to typical lifetime income, it is well documented that individuals exhibit considerable heterogeneity in their preferences about timing of such rewards, and this heterogeneity is correlated with large-stakes intertemporal choices (Falk et al. 2015).
} 
robustness of results to using such an impatience index. The survey also included a question aimed specifically at capturing present-bias and dynamically inconsistent preferences, which asked about postponing. The latter measure provides a Procrastinator Score for each respondent. ${ }^{8}$

To the database of survey module responses, we appended information on several important socio-economic and demographic variables from the HRS Core dataset. ${ }^{9}$ These included age, sex, race/ethnicity, education, marital status, religion, and an indicator of whether the respondent was relatively optimistic about his subjective life expectancy (compared to the relevant actuarial age/sex life table). The respondent's cognitive score was also included as a control, following Dohmen et al. $(2010,2012)$ who found a positive correlation between impatience and cognition for a younger population. In addition we control for variables indicating that the respondent had been told by a doctor that he had cancer, lung disease, a heart condition, a stroke, or had been diagnosed with Alzheimers or dementia. In some models we also control on $(\ln )$ household income. ${ }^{10}$

In what follows, we first offer some descriptive statistics on the time discounting measures derived using the answers our older respondents provided to the HRS module questions. Next, we link the IRR measures to key outcome variables of interest in the HRS. For instance, we evaluate whether people who were more impatient by our measure ended up with less wealth in retirement,

\footnotetext{
${ }^{8}$ The Future Oriented Score is measured by the respondent's answer to the following question: How do you see yourself: are you a person who is generally willing to give up something today in order to benefit from that in the future, or are you not willing to do so? Please use a scale from 0 to 10 , where 0 means you are "completely unwilling to give up something today" and a 10 means you are "very willing to give up something today". Use the values inbetween to indicate where you fall on the scale. The Procrastinator Score is measured by the respondent's answer to this question: How well does the following statement describe you as a person? I tend to postpone things even though it would be better to get them done right away. Use a scale from 0 to 10 , where 0 means "does not describe me at all" and a 10 means "describes me perfectly". Use the values in-between to indicate where you fall on the scale.

${ }^{9}$ Most variables were taken from the RAND HRS datafile, though in a few cases we used the 2014 HRS wave which had not yet been integrated into the RAND file.

${ }^{10}$ Means of all variables appear in Appendix A, and more information on variable construction appears in the Online Appendices.
} 
invested less in their own health via various preventive health behaviors, and were less likely to defer retirement.

\section{Time Discounting Among the Elderly: Results}

Figure 1 reports the distribution of measured discount rates, or internal rates of return (IRR), derived from the respondents' answers to the questions described above. The mean (median) value of the IRR for our older population is $0.54(0.58)$, with a minimum of 0.03 , a maximum of 0.93 , and a standard deviation of $0.35 .^{11}$

Previous studies have used samples that include younger individuals, and have typically found average discount rates that are somewhat lower that we observe for the elderly. For example, using a similar methodology to ours, involving choices between early and delayed monetary payments, Goda et al. (2015) found an average discount rate of 0.29 for the Rand American Life Panel and the Understanding America Study, both datasets that are intended to be representative of US adults. Harrison et al. (2002) find an average discount rate of 0.28 in a representative sample of the Danish adult population, and Dohmen et al. (2012) reported an average discount rate in the range of 0.28 to 0.30 for a representative sample of German adults. Warner and Pleeter (2001) used a different methodology, involving much larger financial stakes than the typical experimental study: They estimated discount rates from the choices of members of the US army, between alternative pension schemes. They found a discount rate in the range of 0.10 to 0.19 for officers, and 0.33 to 0.50 for enlisted soldiers, more or less in line with the previously mentioned experimental studies. Previous studies have also found indications that IRRs increase over the life cycle (see Dohmen et al., 2012, and forthcoming), helping reconcile the higher discount rates that

\footnotetext{
${ }^{11}$ These are computed as described in Online Appendix B. In the paper we report all IRR values compounded semiannually, since results are not particularly sensitive to different compounding periodicities.
} 
we observe among the elderly. An interesting open question is what might cause changing discount rates over the life cycle, something we turn to in later analysis.

Notably, essentially all previous studies that estimate individual discount rates using experiments or intertemporal choices in other settings have reported estimated discount rates that were substantially higher than market interest rates. Such results contrast with the prediction of many economic models that people save only to earn interest, and market interest rates adjust towards rates of time preference. While the subject remains an area of debate, there are some reasonable explanations for the discrepancy. One could be a systematic tendency to overestimate time preference rates, although it is hard to explain the similarity of results across different methodologies. Another is that the motives behind purchases of financial assets, and the mechanisms determining interest rates, are not fully understood, particularly when time preferences are heterogeneous and correlated with other preferences and characteristics.

Figure 1 here

In Table 1 we report linear regressions of time discounting on personal characteristics. IRR is used in the first three columns, where we see a positive and statistically significant effect of age, on the order of about 1 point. Compared to the IRR mean of 54 points, this is about a two percentage point effect. While it is not enormous, it is economically meaningful, and it suggests that rates of impatience rise with age. Interpreted literally, a 15-year increase in age (say from 70 to 85 ) would raise the IRR by about a standard deviation. The magnitude is also quite robust to the inclusion of other controls including sex, race/ethnicity, education, religion, optimism about longevity, health indicators, and income.

Table 1 here 
Results also show that Whites have systematically lower IRRs than nonwhites, by about 9 points (11 percent); there is no statistically significant differential effect for Hispanics, ceteris paribus. The more educated also have lower rates of impatience, such that one additional year of education is associated with a lower IRR of about one point ( 2 percentage points) - or roughly the same as a year of age. Interestingly, scoring higher on the cognitive ability ${ }^{12}$ measure had no impact on measured IRRs, controlling for education. ${ }^{13}$ Including household income does not change results, in contrast to Carvalho et al. (2016) who focus on the poor and conclude that those who are cash-constrained are more present-biased.

Adding controls for self-reported health problems, some of them severe enough to imply reduced life expectancy, boosts the explained variance (R-squared) by about half, and these additional variables prove to be statistically significant as well. For instance those who had been told they had cancer or a heart condition had 6-8 points higher IRRs, or 11-15 percent higher. Economic theory predicts that reduced life expectancy should increase discounting of the future, but empirical evidence has been scarce. One exception is Oster et al. (2013), who study individuals diagnosed with Huntington's disease at an early age; learning about the disease is associated with changes in behavior such as choosing to retire earlier, which could reflect greater discounting of the future. Our sample of the elderly provides another opportunity to shed light on this question, but with direct measures of time discounting, and provides converging evidence with Oster et al. (2013).

We also find that IRRs are higher for individuals diagnosed with a mental condition (dementia or Alzheimers): IRRs are 19 points (35 percent) higher than average. The mechanism

\footnotetext{
12 The measurement of cognition in the HRS is detailed in Fisher et al. (2015).

${ }^{13}$ A number of other studies have studied how cognitive ability affects impatience including Benjamin et al. (2013) and Dohmen et al. (2010), though not for the older population as here.
} 
could potentially be reduced life expectancy, or it could reflect a systematic impact of dementia on decision-making. If dementia leads to more impatient choices, this has important implications for the outcomes of the elderly who are affected by this condition.

The second three columns of Table 1 use the Impatience Index as the dependent variable, which is the normalized sum the IRR and the negative of the self-reported Future Oriented Score. The results are broadly similar to those based on using the IRR measure alone, in that ethnicity, education, mental acuity, and health conditions are all related to impatience in the same directions. There are some differences, for example in that cognitive ability is significantly related to the Impatience Index, while mental shortfall is not, the opposite of the findings for IRR. Also, having a heart condition is not significantly related to the Impatience Index.

\section{Associations between Time Discounting and Key Economic Behaviors}

Tables 2 through 5 show how our IRR and Impatience Index measures are associated with key outcomes of interest. These include respondents' net wealth, a Healthy Behaviors Index, ${ }^{14}$ how well prepared people are for end of life contingencies, and retirement behaviors. For each outcome, we first regress it on the IRR (or the Impatience Index), and then we add the sociodemographic controls used above (age, sex, race/ethnicity, years of education, marital status, cognition score, religion, procrastinator score, and health controls). A final model in each case also included (ln) household income to evaluate whether the impatience variables are sensitive to its inclusion.

Tables 2-5 here

\footnotetext{
${ }^{14}$ This is measured as the number of precautionary health practices undertaken by the respondent such as getting a flu shot, not smoking, not drinking to excess, and having the relevant gender-appropriate annual exams (e.g., prostate exams, Pap and mammograms).
} 
Net Wealth. The first four columns of Table 2 show that, whether we hold other factors constant or not, there is a strong, statistically significant, and powerful relationship between respondents' impatience measures and their net wealth (the latter is measured in thousands). Specifically, those with higher IRRs have lower wealth, and the coefficient magnitudes are large across all four columns. Focusing on the columns including controls, an IRR coefficient of around -375 suggests that someone with an IRR one standard deviation above the mean would have 29 percent less wealth than his counterpart at the mean $\left(=0.35^{*} 375 / 442\right)$. Goda et al. (2013) found a large and significant correlation between time discounting and retirement wealth, for younger age groups, and Hurd and Rohwedder (2013) reported lower wealth for those indicating they had a short planning horizon. Our results are also consistent with the idea that discount rates measured in old age are relevant for explaining variation in retirement wealth.

Smaller but significant negative coefficients are found for the Procrastinator score, while most health effects are not statistically significant. Interestingly, the education effect is positive and significant when household income is excluded. The White coefficient is also positive and consistently significant, suggesting that this group has more net wealth in older years even after conditioning on other controls. Moreover, estimated magnitudes are comparable to the IRR effect: that is, being White versus nonwhite is associated with having 32-48 percent more net wealth (\$145-210/442). Overall, the models account for between 16-20 percent of variation in the IRR variable.

On the right hand side of Table 2 we run similar regressions, but this time focus on the Impatience Index. The findings are very similar to those using the IRR. Individuals who are more impatience according to the index have significantly lower wealth. 
Health. We next turn to an examination of how the Healthy Behaviors Index varies according to the IRR and other factors. The first three columns of Table 3 include the IRR as the key variable of interest, and longer set of controls first excludes, and then includes, the (ln) of household income, to investigate coefficient sensitivity. Results show that people having higher IRRs are less likely to engage in healthy behaviors, and the effects are statistically significant. Quantitatively, they are on the small side: for instance, an individual with a standard deviation higher IRR would have about 0.1 or two percent more healthy behaviors than average $\left(=0.27^{*} 0.35 / 3.3\right) .{ }^{15}$ Chabris et al. (2008) document a relationship between IRRs and health behaviors for several samples of individuals with different age ranges, all much younger than our sample. Sutter et al. (2010) show similar results for high school age students. Our results show that IRRs also matter for health behaviors towards the end of life. We find that age also has a positive and significant coefficient in the regression explaining health behaviors, though the magnitude is again small. People with higher cognition scores also have more healthy behaviors as measured by our Index.

The next three columns substitute the Impatience Index for the IRR. As shown in column 4, individuals who are more impatient according to the index have significantly lower scores on the health index, similar to conclusions based on the IRR measure. The relationships are less precisely estimated and lose statistical significance, however, after controls are added to the regression in columns 5 and 6.

End of Life Provision. We are also interested in whether impatient people are also less likely to put into place appropriate precautions around their end of life challenges. Understanding decisions about end of life care is important, given the large component of end of life care to health care

\footnotetext{
${ }^{15}$ Our findings suggest that, while impatience is relevant for explaining heterogeneity in health behaviors, the contribution is modest in size. This could explain why incentives for health behaviors designed to counteract impatience by making present benefits larger do not have particularly long-lasting effects; see McConnell (2016).
} 
costs in the United States (see De Nardi et al. 2010). We provide some first evidence on whether variation in time discounting is relevant for such decisions, or whether they are mainly driven by other factors. Our End of Life Index is a count of the number of affirmative responses each respondent gave to questions about whether he had long-term care insurance, assigned a power of attorney, a living will, and had discussed end of life medical care plans with others. The mean (median) value of this index is 1.7 (2), with a standard deviation of 1.3 .

Table 4 shows the results from our descriptive regressions. Our sample size is somewhat attenuated since almost six percent of the sample did not respond to all the questions comprising the End of Life Index. The first column confirms a negative and statistically significant relationship of the IRR with the index, so it impatience is inversely related to taking health precautions around the end of life. Nevertheless the coefficient is attenuated and significance falls with the inclusion of other controls. Other significant relationships include the positive and significant effect of age, where 15 additional years of age would be associated with half a point increase in the End of Life score, or an improvement of 27\% (from the mean of 1.7). Whites also score about 0.5-0.6 points higher than nonwhites (36 percent), while Hispanics score 0.7 points (42 percent) lower than non-Hispanics, and both effects are strongly significant. The only other factor which is notably negative associated with making End of Life provisions is being married, such that married individuals score 0.3 points (or 17 percent) below their single counterparts.

The next three columns substitute the Impatience Index for the IRR. In this case, the relationship between impatience and the end of life index remains statistically significant even with all controls in the regression. Overall, the findings indicate that variation in time discounting in old age is related to decisions about end of life care 
Retirement Behavior. Next we turn to an examination of how retirement patterns vary across more, versus less, patient HRS respondents. Two outcomes are of interest in Table 5: Panel A investigates the age at which people initiated their Social Security benefits, or what is often termed the Social Security claiming age, while Panel B focuses on the difference between peoples' actual Social Security claiming age and their expected claiming age. ${ }^{16}$ As before, the first of four models in each case includes only the impatience factor, and then we add additional controls culminating with the inclusion of (ln) household income. The goal once again is to evaluate the robustness of the results across models.

The analysis in Panel A suggests that only age and education are positively and significantly associated with the respondent' Social Security claiming age. Of the medical conditions, only having had a stroke is linked to lower claiming ages. The IRR measure, and the Impatience Index, are both associated with earlier claiming ages, as would be expected if more impatient people place less weight on earning money for future, post-retirement consumption, but these relationships are not statistically significant.

Results in Panel B show that the IRR and Impatience Index are negatively associated with the difference between actual and expected claiming ages. Though the coefficients are not statistically significant in our sample, the most impatient people claimed earlier than expected, which is consistent with the preference reversal behavior of Rabin (2002), mentioned above. Beyond age, little else is associated with this difference other than being Jewish (negative and significant) and having been diagnosed with mental problems (also negative and significant).

Our findings regarding retirement outcomes contrast to some extent with evidence from Schreiber and Weber (2016). They conducted an online survey with roughly 3,000 German

\footnotetext{
${ }^{16}$ The respondent's expected claiming age is taken from the earliest reported HRS wave. Both analyses include only the subset of HRS respondents with nonmissing and nonzero actual and expected claiming ages.
} 
newspaper readers, and find that a measure of present bias is associated with earlier retirement ages, and a greater discrepancy between planned and actual retirement age, in the direction of retiring earlier than expected. One possible explanation for the difference is that they used a measure of present bias that has a different format from ours. Another possible explanation is that they used self-reported retirement age, such that respondents offered their own subjective definition of what it means to be retired. Our approach uses a more objective, although not necessarily better, approach to measuring retirement, namely social security claiming age.

\section{Conclusions and Policy Implications}

Recent policy discussions have focused on what interventions might be designed to address low savings rates (Ashraf et al. 2006), over-consumption of harmful goods such as smoking and drinking (Camerer et al. 2003), avoid poverty (Carvalho et al. 2016), increase financial literacy (Lusardi and Mitchell 2007), and avoid making financial mistakes over the life cycle (Agarwal et al. 2009). Likewise there is substantial interest in finding ways to encourage people to delay retirement and thereby enjoy greater Social Security benefits in old age (Alleva 2016; Maurer et al. forthcoming). Yet few studies have focused on older adults, impatience, and interesting wealth, health, and retirement behaviors. Accordingly, we fill this gap by exploring the extent of and factors associated with impatience in the older population.

Using a purpose-built module in the HRS, we use experimental elicitations of time preferences for money to show that the mean (median) value of the IRR for our older population is $0.54(0.58)$, with a standard deviation of 0.35 . These values are reasonable and confirm to an all-age survey conducted in Germany. Our IRR measures rise with age: thus a 15-year increase in age from 70 to 85 would be associated with about a standard deviation higher IRR. This result is 
robust to a variety of controls. We also show that Whites and the better educated have lower IRRs, while those with health conditions have 11-30 percent higher IRRs. Cognition scores are not statistically associated with our impatience measures.

When we relate our impatience measures to outcomes of interest using multiple regression models, several interesting results emerge. Net wealth is significantly lower for the least patient, probably indicating that the least patient save less and therefore arrive at old age with fewer assets. We also find that the impatient are much less likely to engage in healthy behaviors and to have made provision for end of life challenges. And finally, our analysis shows that Social Security claiming ages are not significantly related to the IRRs, though impatience is associated with people claiming benefits earlier than anticipated.

Our findings add to the literature on discounting behavior as well as to the understanding of older persons' decision processes. They also have implications for policy. For instance, the existence of widespread impatience among older Americans suggests that people may be willing to take less than actuarially fair incentives in exchange for working longer, particularly if they have access to lump sums. Increasing immediate rewards to other behaviors could also encourage choices such as investing in one's health and making end of life decisions in advance of need.

Future work can work can pursue some intriguing questions raised by our findings, about the determinants of time discounting. Once concerns the explanation for an age effect on IRRs. Since almost all data sets measuring IRRs are cross sectional, it has not been possible to disentangle cohort effects from effects of the aging process. Finding that IRRs vary with age in the relatively narrow age band of our sample casts some doubt on the cohort explanation, although the evidence is clearly not definitive. If it is the process of aging that affects IRRs, what is the specific mechanism? One possible mechanism is reduced survival probability, in line with the 
finding that diagnosis of serious health conditions is also associated with higher IRRs. The relationship between mental shortfall and IRRs also hints at a possible, unanticipated consequences of Alzheimers and related conditions, in terms of systematic changes in decision-making, something that calls for further study. 


\section{References}

Agarwal, S., J.C. Driscoll, X. Gabaix, and D. Laibson. (2009). "The Age of Reason: Financial Decisions over the Life Cycle and Implications for Regulation." Brookings Papers on Economic Activity. (2): 51-101.

Alleva, B. (2016). "Discount Rate Specification and the Social Security Claiming Decision." Social Security Bulletin, 76(2): 1-15.

Ashraf, N., D. Karlan, and W. Yin (2006). "Tying Odysseus to the Mast: Evidence from a Commitment Savings Product in the Philippines." Quarterly Journal of Economics. 121(2): 635-672.

Benjamin, Daniel J., Sebastian A. Brown, and Jesse M. Shapiro. 2013. "Who is 'Behavioral?' Cognitive Ability and Anomalous Preferences." Journal of the European Economic Association, 11 (6): 1231-55

Burks, S. V., J. P. Carpenter, L. Goette, and A. Rustichini. (2009). "Cognitive Skills Affect Economic Preferences, Strategic Behavior, and Job Attachment." PNAS 106 (19): 774550.

Carvalho, L.S., S. Meier, and S.W. Wang. (2016). "Poverty and Economic Decision-Making: Evidence from Changes in Financial Resources at Payday." American Economic Review 106(2): 260-294.

Chabris, C. F., Laibson, D., Morris, C. L., Schuldt, J. P., and Taubinsky, D. 2008. "Individual Laboratory-measured Discount Rates Predict Field Behavior." Journal of Risk and Uncertainty. 37(2-3): $237-269$.

De Nardi, M., E. French, und J.B. Jones. 2010. "Why do the Elderly Save? The Role of Medical Expenses." Journal of Political Economy. 118(1): $39-75$.

Dohmen, T., A. Falk, B. Golsteyn, D. Huffman, and U. Sunde. Forthcoming. "Risk Attitudes Across the Life Course." Economic Journal.

Dohmen, T., A. Falk, D. Huffman, and U. Sunde. 2012. "Interpreting Time Horizon Effects in Inter-Temporal Choice," IZA DP No. 6385.

Dohmen, T., A. Falk, D. Huffman, and U. Sunde. 2010. "Are Risk Aversion and Impatience Related to Cognitive Ability?" American Economic Review. 100(3): 1238 - 1260.

Falk, A., A. Becker, T. Dohmen, D. Huffman and U. Sunde. (2014). "An ExperimentallyValidated Survey Module of Economic Preferences." University of Oxford Working Paper.

Falk, A., Becker, A., Dohmen, T. J., Enke, B., Huffman, D., \& Sunde, U. (2015). "The Nature and Predictive Power of Preferences: Global Evidence." (No. 11006). CEPR Discussion Papers.

Goda, G. S., Levy, M., Manchester, C. F., Sojourner, A., and Tasoff, J. (2015). "The Role of Time Preferences and Exponential-Growth Bias in Retirement Savings.” NBER WP 21482.

Harrison, G. W., Lau, M. I., \& Williams, M. B. (2002). "Estimating Individual Discount Rates in Denmark: A Field Experiment." American Economic Review, 92(5), 1606-1617.

Hurd, M and S Rohwedder. (2013). "Heterogeneity in Spending Change at Retirement." The Journal of the Economics of Ageing. 1-2: 60-71.

Lusardi, A. and O.S. Mitchell. (2007). "Baby Boomer Retirement Security: The Roles of Planning, Financial Literacy, and Housing Wealth.” Journal of Monetary Economics. 54(1), 205-224.

Maurer, R., O.S. Mitchell, T. Schimetschek, and R. Rogalla. Forthcoming. "Will They Take the Money and Work? An Empirical Analysis of People's Willingness to Delay Claiming Social Security Benefits for a Lump Sum.” Journal of Risk and Insurance. 
McConnell, M. (2013). "Behavioral Economics and Aging." The Journal of the Economics of Ageing. 1-2: 83-89.

Meier, Stephan and Charles Sprenger. 2015. "The Stability of Time Preferences." Review of Economics and Statistics. 97(2): 273-286.

O'Donoghue, T., and M. Rabin (1999). "Doing it Now or Later." American Economic Review. 89(1): 103-124.

Oster, E., I. Shoulson, and E.R. Dorsey. (2013). "Optimal Expectations and Limited Medical Testing: Evidence from Huntington Disease.” American Economic Review. 103(2): 804830.

Rabin, M. 2002. "A Perspective on Psychology and Economics." European Economic Review. 46(4): $657-685$.

Schreiber, P. and M. Weber. (2016). "The Influence of Time Preferences on Retirement Timing." University of Mannheim Discussion Paper.

Schreiber, P. and M. Weber. (2015). "Time Inconsistent Preferences and the Annuitization Decision." CEPR Discussion Paper No. DP10383. University of Mannheim.

Sunde, U. and T. Dohmen. (2016). "Aging and Preferences." The Journal of the Economics of Ageing. 7: 64-68.

Sutter, M. and M. G. Kocher. 2013. "Impatience and Uncertainty: Experimental Decisions Predict Adolescents' Field Behavior." American Economic Review. 103(1): 510 - 531.

Warner, J. T., and S. Pleeter. (2001). "The Personal Discount Rate: Evidence from Military Downsizing Programs." American Economic Review, 91(1): 33-53. 
Figure 1. Cumulative Distribution of Measured IRR Values for Older (70+) HRS Respondents

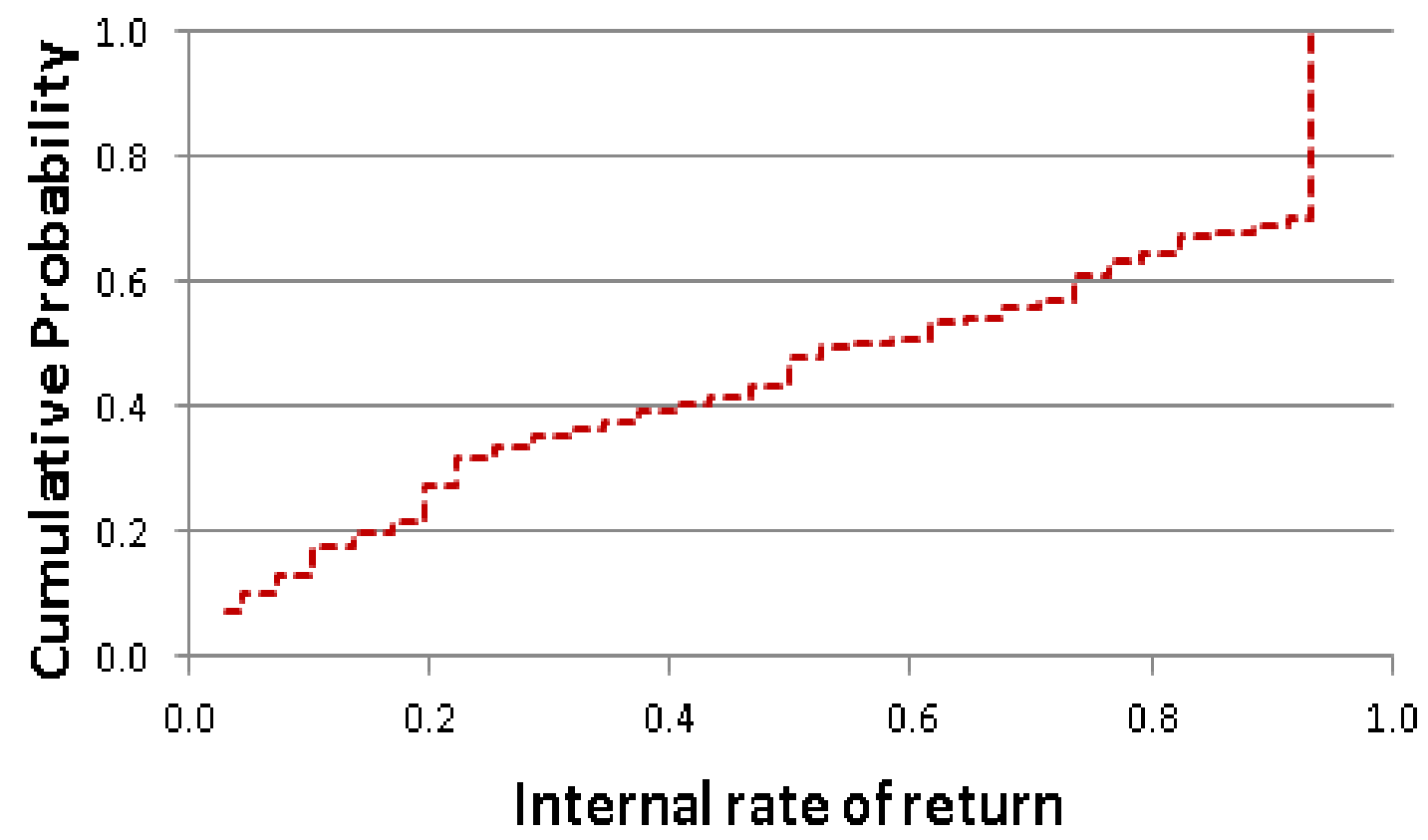

Note: This figure reports the cumulative distribution function (cdf) of internal rates of return (IRR) for the $\mathrm{N}=591$ respondents of a survey module implemented in the 2014 HRS. 
Table 1. Correlates of IRR and Impatience Index Scores among Older HRS Respondents (OLS)

\begin{tabular}{|c|c|c|c|c|c|c|}
\hline \multirow[b]{2}{*}{ Age } & \multicolumn{3}{|c|}{ IRR } & \multicolumn{3}{|c|}{ Impatience Index } \\
\hline & $\begin{array}{c}0.005 * \\
(0.003)\end{array}$ & $\begin{array}{l}0.006 \text { ** } \\
(0.003)\end{array}$ & $\begin{array}{l}0.007 * * \\
(0.003)\end{array}$ & $\begin{array}{c}0.019 * \\
(0.011)\end{array}$ & $\begin{array}{l}0.022 \text { ** } \\
(0.011)\end{array}$ & $\begin{array}{c}0.022 * \\
(0.011)\end{array}$ \\
\hline Male & $\begin{array}{r}-0.005 \\
(0.031)\end{array}$ & $\begin{array}{r}0.025 \\
(0.031)\end{array}$ & $\begin{array}{r}0.026 \\
(0.031)\end{array}$ & $\begin{array}{r}0.155 \\
(0.136)\end{array}$ & $\begin{array}{r}0.223 \\
(0.139)\end{array}$ & $\begin{array}{r}0.220 \\
(0.140)\end{array}$ \\
\hline White & $\begin{array}{l}-0.094 * * \\
(0.041)\end{array}$ & $\begin{array}{l}-0.088 * * \\
(0.040)\end{array}$ & $\begin{array}{l}-0.091 * * \\
(0.040)\end{array}$ & $\begin{array}{l}-0.335 * \\
(0.189)\end{array}$ & $\begin{array}{r}-0.312 \\
(0.190)\end{array}$ & $\begin{array}{r}-0.307 \\
(0.190)\end{array}$ \\
\hline Hispanic & $\begin{array}{c}0.088 * \\
(0.048)\end{array}$ & $\begin{array}{r}0.075 \\
(0.049)\end{array}$ & $\begin{array}{r}0.077 \\
(0.048)\end{array}$ & $\begin{array}{r}0.152 \\
(0.217)\end{array}$ & $\begin{array}{r}0.104 \\
(0.227)\end{array}$ & $\begin{array}{r}0.101 \\
(0.227)\end{array}$ \\
\hline Education years & $\begin{array}{l}-0.011 * \\
(0.006)\end{array}$ & $\begin{array}{l}-0.010 * \\
(0.006)\end{array}$ & $\begin{array}{l}-0.011 * \\
(0.006)\end{array}$ & $\begin{array}{l}-0.057 * * \\
(0.024)\end{array}$ & $\begin{array}{l}-0.054 * * \\
(0.024)\end{array}$ & $\begin{array}{l}-0.053 * * \\
(0.025)\end{array}$ \\
\hline Married & $\begin{array}{r}-0.014 \\
(0.030)\end{array}$ & $\begin{array}{l}-0.031 \\
(0.031)\end{array}$ & $\begin{array}{r}-0.032 \\
(0.032)\end{array}$ & $\begin{array}{l}-0.053 \\
(0.130)\end{array}$ & $\begin{array}{l}-0.089 \\
(0.131)\end{array}$ & $\begin{array}{r}-0.085 \\
(0.140)\end{array}$ \\
\hline Cognition score & $\begin{array}{r}-0.004 \\
(0.004)\end{array}$ & $\begin{array}{l}-0.004 \\
(0.004)\end{array}$ & $\begin{array}{r}-0.004 \\
(0.004)\end{array}$ & $\begin{array}{l}-0.030 * \\
(0.016)\end{array}$ & $\begin{array}{l}-0.031 * \\
(0.016)\end{array}$ & $\begin{array}{l}-0.031 * \\
(0.017)\end{array}$ \\
\hline Christian & $\begin{array}{c}0.024 \\
(0.063)\end{array}$ & $\begin{array}{c}0.048 \\
(0.062)\end{array}$ & $\begin{array}{c}0.054 \\
(0.062)\end{array}$ & $\begin{array}{c}0.033 \\
(0.286)\end{array}$ & $\begin{array}{c}0.129 \\
(0.279)\end{array}$ & $\begin{array}{c}0.119 \\
(0.282)\end{array}$ \\
\hline Jewish & $\begin{array}{l}(0.021) \\
(0.107)\end{array}$ & $\begin{array}{l}(0.013) \\
(0.104)\end{array}$ & $\begin{array}{l}(0.007) \\
(0.104)\end{array}$ & $\begin{array}{c}0.019 \\
(0.450)\end{array}$ & $\begin{array}{c}0.058 \\
(0.451)\end{array}$ & $\begin{array}{c}0.049 \\
(0.452)\end{array}$ \\
\hline Optimistic live to $85+$ & $\begin{array}{r}-0.013 \\
(0.029)\end{array}$ & $\begin{array}{l}-0.020 \\
(0.029)\end{array}$ & $\begin{array}{r}-0.019 \\
(0.029)\end{array}$ & $\begin{array}{l}-0.144 \\
(0.126)\end{array}$ & $\begin{array}{l}-0.154 \\
(0.126)\end{array}$ & $\begin{array}{r}-0.157 \\
(0.127)\end{array}$ \\
\hline Have any cancer & & $\begin{array}{l}(0.077) * * \\
(0.032)\end{array}$ & $\begin{array}{l}(0.078) * * \\
(0.032)\end{array}$ & & $\begin{array}{l}(0.251) * \\
(0.144)\end{array}$ & $\begin{array}{l}(0.248) * \\
(0.145)\end{array}$ \\
\hline Have lung disease & & $\begin{array}{l}(0.006) \\
(0.044)\end{array}$ & $\begin{array}{l}(0.006) \\
(0.045)\end{array}$ & & $\begin{array}{l}(0.204) \\
(0.167)\end{array}$ & $\begin{array}{l}(0.206) \\
(0.169)\end{array}$ \\
\hline Have heart condition & & $\begin{array}{l}(0.059) * * \\
(0.029)\end{array}$ & $\begin{array}{l}(0.059) * * \\
(0.029)\end{array}$ & & $\begin{array}{l}(0.098) \\
(0.130)\end{array}$ & $\begin{array}{l}(0.097) \\
(0.131)\end{array}$ \\
\hline Have stroke & & $\begin{array}{c}0.030 \\
(0.044)\end{array}$ & $\begin{array}{c}0.028 \\
(0.044)\end{array}$ & & $\begin{array}{c}0.178 \\
(0.212)\end{array}$ & $\begin{array}{c}0.180 \\
(0.213)\end{array}$ \\
\hline Mental shortfall & & $\begin{array}{l}0.188 \text { *** } \\
(0.064)\end{array}$ & $\begin{array}{l}0.188 \text { *** } \\
(0.064)\end{array}$ & & $\begin{array}{c}0.118 \\
(0.454)\end{array}$ & $\begin{array}{c}0.120 \\
(0.455)\end{array}$ \\
\hline $\mathrm{Ln}(\mathrm{HH}$ income $)$ & & & $\begin{array}{c}0.003 \\
(0.014)\end{array}$ & & & $\begin{array}{l}(0.007) \\
(0.066)\end{array}$ \\
\hline Intercept & $\begin{array}{c}0.429 * \\
(0.244) \\
\end{array}$ & $\begin{array}{r}0.332 \\
(0.246) \\
\end{array}$ & $\begin{array}{r}0.285 \\
(0.286) \\
\end{array}$ & $\begin{array}{r}0.123 \\
(1.059) \\
\end{array}$ & $\begin{array}{r}-0.153 \\
(1.061) \\
\end{array}$ & $\begin{array}{r}-0.063 \\
(1.222) \\
\end{array}$ \\
\hline$\overline{\mathrm{N}}$ & 591 & 591 & 591 & 575 & 575 & 575 \\
\hline R-squared & 0.084 & 0.117 & 0.119 & 0.075 & 0.092 & 0.092 \\
\hline Mean of dep. Var. & $\begin{array}{l}0.541 \\
0.345\end{array}$ & & & $\begin{array}{r}-0.011 \\
1.324\end{array}$ & & \\
\hline
\end{tabular}

Note: ${ }^{* *}$ Significant at 0.05 level, ${ }^{* * *}$ Significant at 0.01 level. All models include missing value dummies as appropriate. 
Table 2. Association of Financial Outcomes with IRR among Older HRS Respondents (OLS)

\begin{tabular}{|c|c|c|c|c|c|c|c|c|}
\hline \multirow[b]{2}{*}{ IRR } & & \multicolumn{7}{|c|}{ Net wealth $(\$ 1,000)$} \\
\hline & $\begin{array}{l}-534.253 * * * \\
(93.616)\end{array}$ & $\begin{array}{l}-373.473 * * * \\
(82.211)\end{array}$ & $\begin{array}{l}-374.553 * * * \\
(84.991)\end{array}$ & $\begin{array}{l}-379.232 \text { *** } \\
(83.064)\end{array}$ & & & & \\
\hline Impatience index & & & & & $\begin{array}{l}-101.944 * * * \\
(19.822)\end{array}$ & $\begin{array}{l}-69.083 * * * \\
(18.565)\end{array}$ & $\begin{array}{l}-71.109 * * * \\
(19.123)\end{array}$ & $\begin{array}{l}-70.453 * * * \\
(18.405)\end{array}$ \\
\hline Age & & $\begin{array}{r}-4.543 \\
(5.217)\end{array}$ & $\begin{array}{r}-5.249 \\
(5.544)\end{array}$ & $\begin{array}{r}-3.367 \\
(5.466)\end{array}$ & & $\begin{array}{r}-6.020 \\
(5.591)\end{array}$ & $\begin{array}{r}-6.479 \\
(5.929)\end{array}$ & $\begin{array}{r}-4.595 \\
(5.857)\end{array}$ \\
\hline Male & & $\begin{array}{r}4.473 \\
(74.169)\end{array}$ & $\begin{array}{r}17.149 \\
(80.868)\end{array}$ & $\begin{array}{r}20.415 \\
(77.941)\end{array}$ & & $\begin{array}{r}8.679 \\
(75.613)\end{array}$ & $\begin{array}{r}20.393 \\
(82.182)\end{array}$ & $\begin{array}{r}26.997 \\
(79.154)\end{array}$ \\
\hline White & & $\begin{array}{l}201.062 \text { *** } \\
(39.157)\end{array}$ & $\begin{array}{l}208.650 \text { *** } \\
(41.616)\end{array}$ & $\begin{array}{l}145.593 * * * \\
(42.608)\end{array}$ & & $\begin{array}{l}207.460 \text { *** } \\
(42.566)\end{array}$ & $\begin{array}{l}209.679 * * * \\
(45.370)\end{array}$ & $\begin{array}{l}153.888 \text { *** } \\
(47.310)\end{array}$ \\
\hline Hispanic & & $\begin{array}{r}-48.914 \\
(74.061)\end{array}$ & $\begin{array}{r}-62.118 \\
(78.544)\end{array}$ & $\begin{array}{r}36.996 \\
(85.164)\end{array}$ & & $\begin{array}{r}-73.406 \\
(78.752)\end{array}$ & $\begin{array}{r}-80.509 \\
(83.382)\end{array}$ & $\begin{array}{r}14.440 \\
(88.971)\end{array}$ \\
\hline Education years & & $\begin{array}{l}24.212 \text { ** } \\
(11.304)\end{array}$ & $\begin{array}{l}23.729 \text { ** } \\
(11.404)\end{array}$ & $\begin{array}{r}12.923 \\
(11.621)\end{array}$ & & $\begin{array}{l}21.549 * \\
(11.998)\end{array}$ & $\begin{array}{l}22.466 * \\
(12.382)\end{array}$ & $\begin{array}{r}11.644 \\
(12.494)\end{array}$ \\
\hline Married & & $\begin{array}{l}214.471 * * * \\
(73.966)\end{array}$ & $\begin{array}{l}214.323 * * * \\
(75.943)\end{array}$ & $\begin{array}{r}103.489 \\
(74.783)\end{array}$ & & $\begin{array}{l}205.885 * * * \\
(75.654)\end{array}$ & $\begin{array}{l}208.492 * * * \\
(77.160)\end{array}$ & $\begin{array}{r}100.887 \\
(75.658)\end{array}$ \\
\hline Cognition score & & $\begin{array}{l}17.759 \text { *** } \\
(6.624)\end{array}$ & $\begin{array}{l}17.334 * * * \\
(6.558)\end{array}$ & $\begin{array}{l}12.688 \text { ** } \\
(6.306)\end{array}$ & & $\begin{array}{l}18.292 * * * \\
(6.707)\end{array}$ & $\begin{array}{l}17.507 * * * \\
(6.712)\end{array}$ & $\begin{array}{l}12.935 * * \\
(6.389)\end{array}$ \\
\hline Christian & & $\begin{array}{r}-33.980 \\
(216.124)\end{array}$ & $\begin{array}{r}-57.751 \\
(225.440)\end{array}$ & $\begin{array}{r}-34.915 \\
(213.825)\end{array}$ & & $\begin{array}{r}-50.100 \\
(217.257)\end{array}$ & $\begin{array}{r}-71.424 \\
(227.437)\end{array}$ & $\begin{array}{r}-50.172 \\
(215.542)\end{array}$ \\
\hline Jewish & & $\begin{array}{r}865.607 \\
(675.733)\end{array}$ & $\begin{array}{r}821.139 \\
(661.748)\end{array}$ & $\begin{array}{r}811.538 \\
(653.156)\end{array}$ & & $\begin{array}{r}879.778 \\
(681.508)\end{array}$ & $\begin{array}{r}836.961 \\
(667.058)\end{array}$ & $\begin{array}{r}827.451 \\
(659.946)\end{array}$ \\
\hline Procrastinator score & & $\begin{array}{l}-17.127 * \\
(9.020)\end{array}$ & $\begin{array}{l}-15.751 * \\
(9.015)\end{array}$ & $\begin{array}{l}-14.392 * \\
(8.667)\end{array}$ & & $\begin{array}{l}-18.649 * \\
(9.567)\end{array}$ & $\begin{array}{l}-17.064 * \\
(9.609)\end{array}$ & $\begin{array}{l}-15.447 * \\
(9.263)\end{array}$ \\
\hline Optimistic live to $85+$ & & $\begin{array}{r}10.605 \\
(64.979)\end{array}$ & $\begin{array}{r}20.117 \\
(65.332)\end{array}$ & $\begin{array}{r}23.421 \\
(63.509)\end{array}$ & & $\begin{array}{r}2.272 \\
(67.826)\end{array}$ & $\begin{array}{r}13.090 \\
(68.085)\end{array}$ & $\begin{array}{r}15.990 \\
(66.153)\end{array}$ \\
\hline Have any cancer & & & $\begin{array}{r}-55.829 \\
(66.461)\end{array}$ & $\begin{array}{r}-63.720 \\
(65.394)\end{array}$ & & & $\begin{array}{l}-75.605 \\
(65.939)\end{array}$ & $\begin{array}{c}-79.271 \\
(64.675)\end{array}$ \\
\hline Have lung disease & & & $\begin{array}{l}-146.141 * \\
(81.844)\end{array}$ & $\begin{array}{r}-94.842 \\
(79.866)\end{array}$ & & & $\begin{array}{l}-150.682 * \\
(83.452)\end{array}$ & $\begin{array}{r}-98.390 \\
(81.598)\end{array}$ \\
\hline Have heart condition & & & $\begin{array}{r}56.267 \\
(75.584)\end{array}$ & $\begin{array}{r}58.323 \\
(73.656)\end{array}$ & & & $\begin{array}{r}77.853 \\
(78.238)\end{array}$ & $\begin{array}{r}79.832 \\
(76.348)\end{array}$ \\
\hline Have stroke & & & $\begin{array}{r}77.152 \\
(121.505)\end{array}$ & $\begin{array}{r}61.938 \\
(120.456)\end{array}$ & & & $\begin{array}{r}44.959 \\
(125.591)\end{array}$ & $\begin{array}{r}38.974 \\
(125.723)\end{array}$ \\
\hline Mental shortfall & & & $\begin{array}{r}-240.937 \\
(204.395)\end{array}$ & $\begin{array}{l}-306.946 * \\
(180.615)\end{array}$ & & & $\begin{array}{r}-260.737 \\
(216.603)\end{array}$ & $\begin{array}{c}-347.245 * \\
(190.215)\end{array}$ \\
\hline Ln(HH income) & & & & $\begin{array}{l}177.980 * * * \\
(50.826)\end{array}$ & & & & $\begin{array}{l}173.491 * * * \\
(50.291) \\
\end{array}$ \\
\hline Intercept & $\begin{array}{l}728.558 * * * \\
(75.790)\end{array}$ & $\begin{array}{r}143.321 \\
(517.649) \\
\end{array}$ & $\begin{array}{r}223.881 \\
(536.524) \\
\end{array}$ & $\begin{array}{l}-1446.786 * * \\
(734.990)\end{array}$ & $\begin{array}{l}439.801 * * * \\
(33.748)\end{array}$ & $\begin{array}{r}107.282 \\
(541.803) \\
\end{array}$ & $\begin{array}{r}157.032 \\
(562.036) \\
\end{array}$ & $\begin{array}{l}-1482.735 * \\
(756.960)\end{array}$ \\
\hline $\mathrm{N}$ & 582 & 582 & 582 & 582 & 566 & 566 & 566 & 566 \\
\hline R-squared & 0.051 & 0.158 & 0.167 & 0.214 & 0.035 & 0.146 & 0.156 & 0.200 \\
\hline Mean of dep. vars & 442.356 & & & & 441.480 & & & \\
\hline Std.dev. of dep. vars & 816.981 & & & & 820.749 & & & \\
\hline
\end{tabular}

Note: ${ }^{* *}$ Significant at 0.05 level, ${ }^{* * *}$ Significant at 0.01 level. All models include missing value dummies as appropriate. 
Table 3. Association of Health Index with IRR among Older HRS Respondents (OLS)

Health Index

\begin{tabular}{|c|c|c|c|c|c|c|}
\hline IRR & $\begin{array}{l}-0.303^{* *} \\
(0.127)\end{array}$ & $\begin{array}{l}-0.273^{* *} \\
(0.131)\end{array}$ & $\begin{array}{l}-0.274^{* *} \\
(0.131)\end{array}$ & & & \\
\hline Impatience index & & & & $\begin{array}{l}-0.056 * * \\
(0.028)\end{array}$ & $\begin{array}{r}-0.039 \\
(0.029)\end{array}$ & $\begin{array}{r}-0.039 \\
(0.029)\end{array}$ \\
\hline Age & & $\begin{array}{l}0.039 \text { *** } \\
(0.008)\end{array}$ & $\begin{array}{l}0.039 \text { *** } \\
(0.008)\end{array}$ & & $\begin{array}{l}0.038 * * * \\
(0.008)\end{array}$ & $\begin{array}{l}0.038^{* * *} \\
(0.008)\end{array}$ \\
\hline Male & & $\begin{array}{l}-0.249 * * \\
(0.099)\end{array}$ & $\begin{array}{l}-0.249 * * \\
(0.100)\end{array}$ & & $\begin{array}{l}-0.262 * * * \\
(0.101)\end{array}$ & $\begin{array}{l}-0.263 * * * \\
(0.101)\end{array}$ \\
\hline White & & $\begin{array}{r}0.071 \\
(0.121)\end{array}$ & $\begin{array}{r}0.073 \\
(0.122)\end{array}$ & & $\begin{array}{r}0.091 \\
(0.124)\end{array}$ & $\begin{array}{r}0.091 \\
(0.124)\end{array}$ \\
\hline Hispanic & & $\begin{array}{r}0.008 \\
(0.151)\end{array}$ & $\begin{array}{r}0.007 \\
(0.151)\end{array}$ & & $\begin{array}{r}0.016 \\
(0.149)\end{array}$ & $\begin{array}{r}0.015 \\
(0.149)\end{array}$ \\
\hline Education years & & $\begin{array}{r}0.023 \\
(0.017)\end{array}$ & $\begin{array}{r}0.024 \\
(0.017)\end{array}$ & & $\begin{array}{c}0.030 * \\
(0.017)\end{array}$ & $\begin{array}{c}0.030 * \\
(0.018)\end{array}$ \\
\hline Married & & $\begin{array}{r}0.105 \\
(0.092)\end{array}$ & $\begin{array}{r}0.109 \\
(0.097)\end{array}$ & & $\begin{array}{r}0.126 \\
(0.094)\end{array}$ & $\begin{array}{r}0.127 \\
(0.098)\end{array}$ \\
\hline Cognition score & & $\begin{array}{l}0.020 * \\
(0.012)\end{array}$ & $\begin{array}{r}0.021 * \\
(0.012)\end{array}$ & & $\begin{array}{r}0.019 \\
(0.012)\end{array}$ & $\begin{array}{r}0.019 \\
(0.012)\end{array}$ \\
\hline Christian & & $\begin{array}{r}0.207 \\
(0.209)\end{array}$ & $\begin{array}{r}0.207 \\
(0.209)\end{array}$ & & $\begin{array}{r}0.189 \\
(0.212)\end{array}$ & $\begin{array}{r}0.189 \\
(0.212)\end{array}$ \\
\hline Jewish & & $\begin{array}{r}0.087 \\
(0.313)\end{array}$ & $\begin{array}{r}0.087 \\
(0.314)\end{array}$ & & $\begin{array}{r}0.053 \\
(0.307)\end{array}$ & $\begin{array}{r}0.053 \\
(0.308)\end{array}$ \\
\hline Procrastinator score & & $\begin{array}{r}-0.011 \\
(0.013)\end{array}$ & $\begin{array}{r}-0.011 \\
(0.013)\end{array}$ & & $\begin{array}{r}-0.008 \\
(0.013)\end{array}$ & $\begin{array}{r}-0.008 \\
(0.013)\end{array}$ \\
\hline Optimistic live to $85+$ & & $\begin{array}{r}-0.115 \\
(0.087)\end{array}$ & $\begin{array}{r}-0.114 \\
(0.087)\end{array}$ & & $\begin{array}{r}-0.126 \\
(0.089)\end{array}$ & $\begin{array}{l}-0.126 \\
(0.089)\end{array}$ \\
\hline $\mathrm{Ln}(\mathrm{HH}$ income $)$ & & & $\begin{array}{r}-0.006 \\
(0.045) \\
\end{array}$ & & & $\begin{array}{r}-0.001 \\
(0.046) \\
\end{array}$ \\
\hline Intercept & $\begin{array}{l}3.453 * * * \\
(0.080)\end{array}$ & $\begin{array}{l}-0.551 \\
(0.760)\end{array}$ & $\begin{array}{l}-0.499 \\
(0.857)\end{array}$ & $\begin{array}{l}3.287 * * * \\
(0.043)\end{array}$ & $\begin{array}{r}-0.618 \\
(0.771)\end{array}$ & $\begin{array}{r}-0.608 \\
(0.864)\end{array}$ \\
\hline $\bar{N}$ & 516 & 516 & 516 & 502 & 502 & 502 \\
\hline R-squared & 0.011 & 0.102 & 0.102 & 0.007 & 0.098 & 0.098 \\
\hline Mean of dep. vars & 3.291 & & & 3.287 & & \\
\hline Std.dev. of dep. vars & 0.978 & & & 0.973 & & \\
\hline
\end{tabular}

Note: ** Significant at 0.05 level, $* * *$ Significant at 0.01 level. All models include missing value dummies as appropriate. 
Table 4. Association of End of Life Index with IRR among Older HRS Respondents (OLS)

\begin{tabular}{|c|c|c|c|c|c|c|c|c|}
\hline \multirow[b]{2}{*}{ IRR } & & \multicolumn{7}{|c|}{ End of Life Index } \\
\hline & $\begin{array}{l}-0.599 \text { *** } \\
(0.164)\end{array}$ & $\begin{array}{l}-0.216 \\
(0.159)\end{array}$ & $\begin{array}{c}-0.199 \\
(0.162)\end{array}$ & $\begin{array}{c}-0.196 \\
(0.163)\end{array}$ & & & & \\
\hline Impatience index & & & & & $\begin{array}{l}-0.150 \text { *** } \\
(0.036)\end{array}$ & $\begin{array}{l}-0.065 * \\
(0.035)\end{array}$ & $\begin{array}{l}-0.065 * \\
(0.035)\end{array}$ & $\begin{array}{l}-0.064 * \\
(0.035)\end{array}$ \\
\hline Age & & $\begin{array}{l}0.031 \text { ** } \\
(0.012)\end{array}$ & $\begin{array}{l}0.027 \text { ** } \\
(0.012)\end{array}$ & $\begin{array}{l}0.027 \text { ** } \\
(0.012)\end{array}$ & & $\begin{array}{l}0.031 \text { ** } \\
(0.012)\end{array}$ & $\begin{array}{l}0.028 \text { ** } \\
(0.012)\end{array}$ & $\begin{array}{l}0.028 \text { ** } \\
(0.012)\end{array}$ \\
\hline Male & & $\begin{array}{l}-0.136 \\
(0.114)\end{array}$ & $\begin{array}{l}-0.177 \\
(0.119)\end{array}$ & $\begin{array}{r}-0.178 \\
(0.119)\end{array}$ & & $\begin{array}{r}-0.132 \\
(0.115)\end{array}$ & $\begin{array}{l}-0.166 \\
(0.119)\end{array}$ & $\begin{array}{c}-0.166 \\
(0.119)\end{array}$ \\
\hline White & & $\begin{array}{l}0.563 \text { *** } \\
(0.145)\end{array}$ & $\begin{array}{l}0.556 \text { *** } \\
(0.145)\end{array}$ & $\begin{array}{l}0.549 \text { *** } \\
(0.145)\end{array}$ & & $\begin{array}{l}0.519 \text { *** } \\
(0.145)\end{array}$ & $\begin{array}{l}0.511 \\
(0.145)\end{array}$ & $\begin{array}{l}0.504 \text { *** } \\
(0.145)\end{array}$ \\
\hline Hispanic & & $\begin{array}{l}-0.718 * * * \\
(0.159)\end{array}$ & $\begin{array}{l}-0.698 \text { *** } \\
(0.163)\end{array}$ & $\begin{array}{l}-0.678 \text { *** } \\
(0.166)\end{array}$ & & $\begin{array}{l}-0.735 \text { *** } \\
(0.157)\end{array}$ & $\begin{array}{l}-0.715 * * * \\
(0.160)\end{array}$ & $\begin{array}{l}-0.696 \text { *** } \\
(0.163)\end{array}$ \\
\hline Education years & & $\begin{array}{l}0.101 \text { *** } \\
(0.020)\end{array}$ & $\begin{array}{l}0.100 \text { *** } \\
(0.020)\end{array}$ & $\begin{array}{l}0.097 \text { *** } \\
(0.020)\end{array}$ & & $\begin{array}{l}0.100 \text { *** } \\
(0.020)\end{array}$ & $\begin{array}{l}0.099 * * * \\
(0.020)\end{array}$ & $\begin{array}{l}0.098 \text { *** } \\
(0.020)\end{array}$ \\
\hline Married & & $\begin{array}{l}-0.284 * * \\
(0.110)\end{array}$ & $\begin{array}{l}-0.262 * * \\
(0.112)\end{array}$ & $\begin{array}{l}-0.302 * * \\
(0.122)\end{array}$ & & $\begin{array}{l}-0.290 * * * \\
(0.110)\end{array}$ & $\begin{array}{l}-0.267 * * \\
(0.113)\end{array}$ & $\begin{array}{l}-0.304 \text { ** } \\
(0.123)\end{array}$ \\
\hline Cognition score & & $\begin{array}{r}0.022 \\
(0.014)\end{array}$ & $\begin{array}{r}0.021 \\
(0.014)\end{array}$ & $\begin{array}{r}0.019 \\
(0.014)\end{array}$ & & $\begin{array}{c}0.023 \\
(0.014)\end{array}$ & $\begin{array}{r}0.022 \\
(0.014)\end{array}$ & $\begin{array}{r}0.020 \\
(0.014)\end{array}$ \\
\hline Christian & & $\begin{array}{r}0.326 \\
(0.256)\end{array}$ & $\begin{array}{r}0.288 \\
(0.248)\end{array}$ & $\begin{array}{r}0.280 \\
(0.252)\end{array}$ & & $\begin{array}{r}0.320 \\
(0.251)\end{array}$ & $\begin{array}{r}0.287 \\
(0.245)\end{array}$ & $\begin{array}{r}0.281 \\
(0.248)\end{array}$ \\
\hline Jewish & & $\begin{array}{r}0.634 \\
(0.504)\end{array}$ & $\begin{array}{r}0.555 \\
(0.503)\end{array}$ & $\begin{array}{r}0.514 \\
(0.505)\end{array}$ & & $\begin{array}{r}0.631 \\
(0.501)\end{array}$ & $\begin{array}{r}0.560 \\
(0.503)\end{array}$ & $\begin{array}{r}0.522 \\
(0.505)\end{array}$ \\
\hline Procrastinator score & & $\begin{array}{l}-0.008 \\
(0.015)\end{array}$ & $\begin{array}{l}-0.008 \\
(0.015)\end{array}$ & $\begin{array}{l}-0.008 \\
(0.015)\end{array}$ & & $\begin{array}{l}-0.008 \\
(0.015)\end{array}$ & $\begin{array}{l}-0.008 \\
(0.015)\end{array}$ & $\begin{array}{l}-0.007 \\
(0.015)\end{array}$ \\
\hline Optimistic live to $85+$ & & $\begin{array}{l}-0.015 \\
(0.107)\end{array}$ & $\begin{array}{r}0.005 \\
(0.108)\end{array}$ & $\begin{array}{r}0.002 \\
(0.109)\end{array}$ & & $\begin{array}{l}-0.015 \\
(0.108)\end{array}$ & $\begin{array}{r}0.003 \\
(0.109)\end{array}$ & $\begin{array}{l}-0.001 \\
(0.110)\end{array}$ \\
\hline Have any cancer & & & $\begin{array}{r}0.110 \\
(0.117)\end{array}$ & $\begin{array}{r}0.112 \\
(0.117)\end{array}$ & & & $\begin{array}{r}0.071 \\
(0.119)\end{array}$ & $\begin{array}{r}0.074 \\
(0.119)\end{array}$ \\
\hline Have lung disease & & & $\begin{array}{l}-0.068 \\
(0.154)\end{array}$ & $\begin{array}{l}-0.046 \\
(0.154)\end{array}$ & & & $\begin{array}{l}-0.065 \\
(0.154)\end{array}$ & $\begin{array}{l}-0.046 \\
(0.154)\end{array}$ \\
\hline Have heart condition & & & $\begin{array}{r}0.167 \\
(0.115)\end{array}$ & $\begin{array}{r}0.161 \\
(0.116)\end{array}$ & & & $\begin{array}{r}0.168 \\
(0.116)\end{array}$ & $\begin{array}{r}0.164 \\
(0.117)\end{array}$ \\
\hline Have stroke & & & $\begin{array}{l}-0.068 \\
(0.155)\end{array}$ & $\begin{array}{l}-0.074 \\
(0.154)\end{array}$ & & & $\begin{array}{l}-0.082 \\
(0.159)\end{array}$ & $\begin{array}{l}-0.088 \\
(0.159)\end{array}$ \\
\hline Mental shortfall & & & $\begin{array}{r}0.302 \\
(0.247)\end{array}$ & $\begin{array}{r}0.282 \\
(0.241)\end{array}$ & & & $\begin{array}{c}0.411 \text { * } \\
(0.238)\end{array}$ & $\begin{array}{r}0.383 \\
(0.234)\end{array}$ \\
\hline $\mathrm{Ln}(\mathrm{HH}$ income $)$ & & & & $\begin{array}{r}0.053 \\
(0.060) \\
\end{array}$ & & & & $\begin{array}{r}0.049 \\
(0.060) \\
\end{array}$ \\
\hline Intercept & $\begin{array}{l}1.973 \text { *** } \\
(0.105)\end{array}$ & $\begin{array}{l}-2.839 * * * \\
(1.028)\end{array}$ & $\begin{array}{l}-2.560 * * \\
(1.028)\end{array}$ & $\begin{array}{l}-2.987 * * \\
(1.187)\end{array}$ & $\begin{array}{l}1.645 \text { *** } \\
(0.057)\end{array}$ & $\begin{array}{l}-2.980 * * * \\
(1.043)\end{array}$ & $\begin{array}{l}-2.695 * * * \\
(1.039)\end{array}$ & $\begin{array}{l}-3.106 * * \\
(1.206)\end{array}$ \\
\hline$\overline{\mathrm{N}}$ & 487 & 487 & 487 & 487 & 479 & 479 & 479 & 479 \\
\hline R-squared & 0.026 & 0.247 & 0.254 & 0.256 & 0.032 & 0.250 & 0.257 & 0.258 \\
\hline $\begin{array}{l}\text { Mean of dep. var. } \\
\text { Std.dev. of dep. var. }\end{array}$ & $\begin{array}{l}1.655 \\
1.264\end{array}$ & & & & $\begin{array}{l}1.649 \\
1.265\end{array}$ & & & \\
\hline
\end{tabular}

Note: ** Significant at 0.05 level, *** Significant at 0.01 level. All models include missing value dummies as appropriate. 
Table 5. Association of Social Security Claiming Age and Difference between Expected and Actual Social Security Claiming Age, and Impatience among Older HRS Respondents (OLS)

\begin{tabular}{|c|c|c|c|c|c|c|c|c|}
\hline & A. Age rec & ceived Social & 1 Security & & & & & \\
\hline$\overline{\mathrm{IRR}}$ & $\begin{array}{l}-0.406 \\
(0.273)\end{array}$ & $\begin{array}{l}-0.443 \\
(0.287)\end{array}$ & $\begin{array}{l}-0.437 \\
(0.288)\end{array}$ & $\begin{array}{l}-0.414 \\
(0.288)\end{array}$ & & & & \\
\hline Impatience Index & & & & & $\begin{array}{l}-0.055 \\
(0.068)\end{array}$ & $\begin{array}{l}-0.065 \\
(0.069)\end{array}$ & $\begin{array}{r}-0.054 \\
(0.069)\end{array}$ & $\begin{array}{l}-0.052 \\
(0.069)\end{array}$ \\
\hline Age & & $\begin{array}{l}0.092 \text { *** } \\
(0.022)\end{array}$ & $\begin{array}{l}0.099 \text { *** } \\
(0.023)\end{array}$ & $\begin{array}{l}0.097 * * * \\
(0.023)\end{array}$ & & $\begin{array}{l}0.091 * * * \\
(0.023)\end{array}$ & $\begin{array}{l}0.097 \text { *** } \\
(0.024)\end{array}$ & $\begin{array}{l}0.097 \text { *** } \\
(0.024)\end{array}$ \\
\hline Male & & $\begin{array}{r}0.236 \\
(0.204)\end{array}$ & $\begin{array}{r}0.288 \\
(0.207)\end{array}$ & $\begin{array}{r}0.281 \\
(0.208)\end{array}$ & & $\begin{array}{r}0.238 \\
(0.207)\end{array}$ & $\begin{array}{r}0.277 \\
(0.211)\end{array}$ & $\begin{array}{r}0.274 \\
(0.212)\end{array}$ \\
\hline White & & $\begin{array}{l}-0.273 \\
(0.307)\end{array}$ & $\begin{array}{l}-0.300 \\
(0.312)\end{array}$ & $\begin{array}{l}-0.302 \\
(0.316)\end{array}$ & & $\begin{array}{l}-0.254 \\
(0.321)\end{array}$ & $\begin{array}{l}-0.287 \\
(0.327)\end{array}$ & $\begin{array}{l}-0.299 \\
(0.330)\end{array}$ \\
\hline Hispanic & & $\begin{array}{c}0.556 \text { * } \\
(0.335)\end{array}$ & $\begin{array}{r}0.483 \\
(0.344)\end{array}$ & $\begin{array}{r}0.489 \\
(0.347)\end{array}$ & & $\begin{array}{r}0.519 \\
(0.336)\end{array}$ & $\begin{array}{r}0.443 \\
(0.345)\end{array}$ & $\begin{array}{r}0.452 \\
(0.347)\end{array}$ \\
\hline Education years & & $\begin{array}{l}0.120^{* * *} \\
(0.034)\end{array}$ & $\begin{array}{l}0.120 \text { *** } \\
(0.035)\end{array}$ & $\begin{array}{l}0.113 \text { *** } \\
(0.037)\end{array}$ & & $\begin{array}{l}0.120 \text { *** } \\
(0.036)\end{array}$ & $\begin{array}{l}0.121 \text { *** } \\
(0.036)\end{array}$ & $\begin{array}{l}0.116 \text { *** } \\
(0.038)\end{array}$ \\
\hline Married & & $\begin{array}{l}-0.019 \\
(0.202)\end{array}$ & $\begin{array}{c}-0.032 \\
(0.205)\end{array}$ & $\begin{array}{l}-0.093 \\
(0.222)\end{array}$ & & $\begin{array}{l}-0.001 \\
(0.206)\end{array}$ & $\begin{array}{c}-0.012 \\
(0.210)\end{array}$ & $\begin{array}{l}-0.079 \\
(0.224)\end{array}$ \\
\hline Cognition score & & $\begin{array}{l}-0.041 \\
(0.025)\end{array}$ & $\begin{array}{r}-0.039 \\
(0.026)\end{array}$ & $\begin{array}{l}-0.043 * \\
(0.026)\end{array}$ & & $\begin{array}{l}-0.040 \\
(0.026)\end{array}$ & $\begin{array}{c}-0.038 \\
(0.026)\end{array}$ & $\begin{array}{r}-0.042 \\
(0.026)\end{array}$ \\
\hline Christian & & $\begin{array}{l}-0.415 \\
(0.394)\end{array}$ & $\begin{array}{l}-0.456 \\
(0.413)\end{array}$ & $\begin{array}{l}-0.490 \\
(0.415)\end{array}$ & & $\begin{array}{l}-0.421 \\
(0.394)\end{array}$ & $\begin{array}{l}-0.461 \\
(0.411)\end{array}$ & $\begin{array}{l}-0.483 \\
(0.414)\end{array}$ \\
\hline Jewish & & $\begin{array}{r}1.103 \\
(0.915)\end{array}$ & $\begin{array}{r}1.141 \\
(0.884)\end{array}$ & $\begin{array}{r}1.044 \\
(0.874)\end{array}$ & & $\begin{array}{r}1.095 \\
(0.907)\end{array}$ & $\begin{array}{r}1.124 \\
(0.882)\end{array}$ & $\begin{array}{r}1.027 \\
(0.873)\end{array}$ \\
\hline Procrastinator score & & $\begin{array}{l}-0.003 \\
(0.029)\end{array}$ & $\begin{array}{r}0.005 \\
(0.028)\end{array}$ & $\begin{array}{r}0.006 \\
(0.028)\end{array}$ & & $\begin{array}{l}-0.004 \\
(0.029)\end{array}$ & $\begin{array}{r}0.003 \\
(0.028)\end{array}$ & $\begin{array}{r}0.004 \\
(0.029)\end{array}$ \\
\hline Optimistic live to $85+$ & & $\begin{array}{r}0.182 \\
(0.189)\end{array}$ & $\begin{array}{r}0.154 \\
(0.191)\end{array}$ & $\begin{array}{r}0.144 \\
(0.191)\end{array}$ & & $\begin{array}{r}0.197 \\
(0.192)\end{array}$ & $\begin{array}{r}0.171 \\
(0.194)\end{array}$ & $\begin{array}{r}0.158 \\
(0.194)\end{array}$ \\
\hline Have any cancer & & & $\begin{array}{r}0.152 \\
(0.216)\end{array}$ & $\begin{array}{r}0.164 \\
(0.216)\end{array}$ & & & $\begin{array}{r}0.176 \\
(0.226)\end{array}$ & $\begin{array}{r}0.188 \\
(0.226)\end{array}$ \\
\hline Have lung disease & & & $\begin{array}{l}-0.200 \\
(0.258)\end{array}$ & $\begin{array}{l}-0.155 \\
(0.259)\end{array}$ & & & $\begin{array}{l}-0.206 \\
(0.265)\end{array}$ & $\begin{array}{l}-0.164 \\
(0.266)\end{array}$ \\
\hline Have heart condition & & & $\begin{array}{l}-0.302 \\
(0.206)\end{array}$ & $\begin{array}{l}-0.300 \\
(0.206)\end{array}$ & & & $\begin{array}{l}-0.309 \\
(0.211)\end{array}$ & $\begin{array}{l}-0.306 \\
(0.211)\end{array}$ \\
\hline Have stroke & & & $\begin{array}{l}-0.614 \text { ** } \\
(0.252)\end{array}$ & $\begin{array}{l}-0.611 * * \\
(0.250)\end{array}$ & & & $\begin{array}{l}-0.601 * * \\
(0.262)\end{array}$ & $\begin{array}{l}-0.600 \text { ** } \\
(0.260)\end{array}$ \\
\hline Mental shortfall & & & $\begin{array}{l}-0.474 \\
(0.736)\end{array}$ & $\begin{array}{l}-0.544 \\
(0.758)\end{array}$ & & & $\begin{array}{l}-0.575 \\
(0.729)\end{array}$ & $\begin{array}{l}-0.651 \\
(0.751)\end{array}$ \\
\hline $\mathrm{Ln}(\mathrm{HH}$ income $)$ & & & & $\begin{array}{r}0.092 \\
(0.123) \\
\end{array}$ & & & & $\begin{array}{r}0.097 \\
(0.124) \\
\end{array}$ \\
\hline Intercept & $\begin{array}{l}63.622 \text { *** } \\
(0.172)\end{array}$ & $\begin{array}{l}56.207 \text { *** } \\
(1.901)\end{array}$ & $\begin{array}{l}55.879 * * * \\
(1.961)\end{array}$ & $\begin{array}{l}55.253 \text { *** } \\
(2.177)\end{array}$ & $\begin{array}{l}63.410 * * * \\
(0.096)\end{array}$ & $\begin{array}{l}55.995 * * * \\
(1.947)\end{array}$ & $\begin{array}{l}55.693 \text { *** } \\
(2.009)\end{array}$ & $\begin{array}{l}54.944 * * * \\
(2.244)\end{array}$ \\
\hline$\overline{\mathrm{N}}$ & 464 & 464 & 464 & 464 & 455 & 455 & 455 & 455 \\
\hline R-squared & 0.005 & 0.098 & 0.122 & 0.125 & 0.002 & 0.092 & 0.116 & 0.119 \\
\hline $\begin{array}{l}\text { Mean of dep. vars } \\
\text { Std.dev. of dep. vars }\end{array}$ & $\begin{array}{r}63.404 \\
2.033\end{array}$ & & & & $\begin{array}{r}63.411 \\
2.045\end{array}$ & & & \\
\hline
\end{tabular}

(cont) 
Table 5 (cont)

\begin{tabular}{|c|c|c|c|c|c|c|c|c|}
\hline \multirow{2}{*}{$\overline{\text { IRR }}$} & \multicolumn{8}{|c|}{ B. Actual - Expected Soc Sec Claim Age } \\
\hline & $\begin{array}{l}-0.039 \\
(0.370)\end{array}$ & $\begin{array}{l}-0.111 \\
(0.403)\end{array}$ & $\begin{array}{l}-0.136 \\
(0.409)\end{array}$ & $\begin{array}{r}-0.125 \\
(0.409)\end{array}$ & & & & \\
\hline Impatience Index & & & & & $\begin{array}{r}-0.013 \\
(0.090)\end{array}$ & $\begin{array}{r}0.000 \\
(0.092)\end{array}$ & $\begin{array}{r}-0.006 \\
(0.095)\end{array}$ & $\begin{array}{r}-0.013 \\
(0.095)\end{array}$ \\
\hline Age & & $\begin{array}{l}0.092 \quad * * \\
(0.043)\end{array}$ & $\begin{array}{l}0.090 \text { ** } \\
(0.043)\end{array}$ & $\begin{array}{l}0.088 \text { ** } \\
(0.044)\end{array}$ & & $\begin{array}{l}0.090 \text { ** } \\
(0.043)\end{array}$ & $\begin{array}{l}0.089 \text { ** } \\
(0.044)\end{array}$ & $\begin{array}{l}0.087 \text { ** } \\
(0.044)\end{array}$ \\
\hline Male & & $\begin{array}{l}-0.159 \\
(0.304)\end{array}$ & $\begin{array}{r}-0.090 \\
(0.294)\end{array}$ & $\begin{array}{r}-0.142 \\
(0.296)\end{array}$ & & $\begin{array}{l}-0.201 \\
(0.306)\end{array}$ & $\begin{array}{l}-0.135 \\
(0.297)\end{array}$ & $\begin{array}{r}-0.177 \\
(0.300)\end{array}$ \\
\hline White & & $\begin{array}{l}-0.289 \\
(0.389)\end{array}$ & $\begin{array}{l}-0.209 \\
(0.406)\end{array}$ & $\begin{array}{c}-0.148 \\
(0.407)\end{array}$ & & $\begin{array}{r}-0.290 \\
(0.403)\end{array}$ & $\begin{array}{l}-0.211 \\
(0.423)\end{array}$ & $\begin{array}{r}-0.150 \\
(0.423)\end{array}$ \\
\hline Hispanic & & $\begin{array}{l}0.424 \\
(0.550)\end{array}$ & $\begin{array}{r}0.268 \\
(0.559)\end{array}$ & $\begin{array}{r}0.219 \\
(0.563)\end{array}$ & & $\begin{array}{r}0.397 \\
(0.551)\end{array}$ & $\begin{array}{r}0.253 \\
(0.560)\end{array}$ & $\begin{array}{r}0.206 \\
(0.564)\end{array}$ \\
\hline Education years & & $\begin{array}{l}0.037 \\
(0.053)\end{array}$ & $\begin{array}{r}0.037 \\
(0.054)\end{array}$ & $\begin{array}{r}0.045 \\
(0.055)\end{array}$ & & $\begin{array}{r}0.029 \\
(0.055)\end{array}$ & $\begin{array}{r}0.030 \\
(0.056)\end{array}$ & $\begin{array}{r}0.040 \\
(0.057)\end{array}$ \\
\hline Married & & $\begin{array}{l}0.112 \\
(0.323)\end{array}$ & $\begin{array}{r}0.069 \\
(0.324)\end{array}$ & $\begin{array}{r}0.182 \\
(0.354)\end{array}$ & & $\begin{array}{r}0.156 \\
(0.324)\end{array}$ & $\begin{array}{r}0.105 \\
(0.325)\end{array}$ & $\begin{array}{r}0.224 \\
(0.355)\end{array}$ \\
\hline Cognition score & & $\begin{array}{l}0.024 \\
(0.044)\end{array}$ & $\begin{array}{r}0.021 \\
(0.044)\end{array}$ & $\begin{array}{r}0.024 \\
(0.044)\end{array}$ & & $\begin{array}{r}0.031 \\
(0.044)\end{array}$ & $\begin{array}{r}0.027 \\
(0.045)\end{array}$ & $\begin{array}{r}0.029 \\
(0.045)\end{array}$ \\
\hline Christian & & $\begin{array}{l}0.108 \\
(0.503)\end{array}$ & $\begin{array}{r}0.149 \\
(0.500)\end{array}$ & $\begin{array}{r}0.037 \\
(0.507)\end{array}$ & & $\begin{array}{r}0.097 \\
(0.507)\end{array}$ & $\begin{array}{r}0.134 \\
(0.506)\end{array}$ & $\begin{array}{r}0.046 \\
(0.512)\end{array}$ \\
\hline Jewish & & $\begin{array}{l}-2.710 \text { **: } \\
(0.960)\end{array}$ & $\begin{array}{l}-2.781 * * * \\
(1.004)\end{array}$ & $\begin{array}{l}-2.775 * * * \\
(1.009)\end{array}$ & & $\begin{array}{l}-2.691 \text { *** } \\
(0.962)\end{array}$ & $\begin{array}{l}-2.758 * * * \\
(1.011)\end{array}$ & $\begin{array}{l}-2.736 \text { *** } \\
(1.021)\end{array}$ \\
\hline Procrastinator score & & $\begin{array}{l}0.029 \\
(0.044)\end{array}$ & $\begin{array}{r}0.031 \\
(0.044)\end{array}$ & $\begin{array}{r}0.031 \\
(0.044)\end{array}$ & & $\begin{array}{r}0.028 \\
(0.044)\end{array}$ & $\begin{array}{r}0.030 \\
(0.044)\end{array}$ & $\begin{array}{r}0.029 \\
(0.044)\end{array}$ \\
\hline Optimistic live to $85+$ & & $\begin{array}{r}0.342 \\
(0.283)\end{array}$ & $\begin{array}{r}0.368 \\
(0.286)\end{array}$ & $\begin{array}{r}0.368 \\
(0.287)\end{array}$ & & $\begin{array}{r}0.366 \\
(0.286)\end{array}$ & $\begin{array}{r}0.388 \\
(0.289)\end{array}$ & $\begin{array}{r}0.387 \\
(0.290)\end{array}$ \\
\hline Have any cancer & & & $\begin{array}{r}-0.312 \\
(0.332)\end{array}$ & $\begin{array}{l}-0.329 \\
(0.331)\end{array}$ & & & $\begin{array}{r}-0.264 \\
(0.338)\end{array}$ & $\begin{array}{l}-0.276 \\
(0.337)\end{array}$ \\
\hline Have lung disease & & & $\begin{array}{l}-0.643 \\
(0.411)\end{array}$ & $\begin{array}{l}-0.687 * \\
(0.409)\end{array}$ & & & $\begin{array}{l}-0.592 \\
(0.423)\end{array}$ & $\begin{array}{l}-0.656 \\
(0.423)\end{array}$ \\
\hline Have heart condition & & & $\begin{array}{r}0.080 \\
(0.284)\end{array}$ & $\begin{array}{r}0.075 \\
(0.284)\end{array}$ & & & $\begin{array}{r}0.051 \\
(0.285)\end{array}$ & $\begin{array}{r}0.056 \\
(0.286)\end{array}$ \\
\hline Have stroke & & & $\begin{array}{r}0.228 \\
(0.308)\end{array}$ & $\begin{array}{r}0.212 \\
(0.312)\end{array}$ & & & $\begin{array}{r}0.242 \\
(0.324)\end{array}$ & $\begin{array}{r}0.214 \\
(0.329)\end{array}$ \\
\hline Mental shortfall & & & $\begin{array}{l}-2.136 * * * \\
(0.565)\end{array}$ & $\begin{array}{l}-2.115 * * * \\
(0.600)\end{array}$ & & & $\begin{array}{l}-2.201 * * * \\
(0.616)\end{array}$ & $\begin{array}{l}-2.170 * * * \\
(0.653)\end{array}$ \\
\hline $\mathrm{Ln}$ (HH income) & & & & $\begin{array}{r}-0.131 \\
(0.165) \\
\end{array}$ & & & & $\begin{array}{r}-0.138 \\
(0.164) \\
\end{array}$ \\
\hline Intercept & $\begin{array}{r}-0.170 \\
(0.248) \\
\end{array}$ & $\begin{array}{l}-8.408 * * \\
(3.433)\end{array}$ & $\begin{array}{l}-8.149 \text { ** } \\
(3.500)\end{array}$ & $\begin{array}{l}-6.753 * \\
(3.825) \\
\end{array}$ & $\begin{array}{r}-0.188 \\
(0.134)\end{array}$ & $\begin{array}{l}-8.345 \text { ** } \\
(3.487)\end{array}$ & $\begin{array}{l}-8.199 * * \\
(3.545)\end{array}$ & $\begin{array}{l}-6.790 * \\
(3.882) \\
\end{array}$ \\
\hline $\mathrm{N}$ & 349 & 349 & 349 & 349 & 343 & 343 & 343 & 343 \\
\hline R-squared & 0.000 & 0.056 & 0.071 & 0.079 & 0.000 & 0.054 & 0.067 & 0.073 \\
\hline Mean of dep. vars & -0.191 & & & & -0.188 & & & \\
\hline Std.dev. of dep. vars & 2.463 & & & & 2.469 & & & \\
\hline
\end{tabular}

Note: ${ }^{* *}$ Significant at 0.05 level, ${ }^{* * *}$ Significant at 0.01 level. All models include missing value dummies as appropriate. 


\section{Appendix A. Variables Used in the Analysis}

\section{Economic and Health Outcomes}

- Net Wealth (All household assets minus debt; includes house)

- Health Index: sum of scores for had flu shot, as appropriate got mammo/Pap smear or prostate test; nonsmoker; healthy drinker ( $\leq 1$ drink/day)

- End of Life Index: sum of scores for had LTC, had living will, had disability care, had power of attorney

- Impatience Index sum of normalized IRR and (the negative of) Future Oriented Score (the latter is measured on a scale from 0 to 10 , where 0 means $\mathrm{R}$ is "completely unwilling to give up something today" and a 10 means "very willing to give up something today").

- Age Received SocSec: Actual age claimed Social Security

- Act-Expected SocSec Claim Age: Actual - expected (at baseline) Social Security claim age

Preferences and Socio-Demographic Controls

- Internal Rate of Return (IRR): for definition see Appendix B

- Procrastinator Score

- Age

- Male

- Race/ethnicity

- Education (years)

- Married

- Cognition Score

- Christian/Jewish/other

- Optimistic live to 85+

- Have cancer/lung disease/heart condition/stroke

- Mental shortfall

- Ln (HH income) 


\section{Appendix B. Descriptive stats for Key Variables}

\begin{tabular}{lrrrrr}
\hline & Mean & St.dev. & \multicolumn{1}{c}{ Min } & Median & Max \\
\hline IRR & 0.54 & 0.35 & 0.03 & 0.58 & 0.93 \\
Net wealth $(\$ 1,000)$ & 442 & 817 & -260 & 192 & 7,919 \\
Health Index & 3.29 & 0.98 & 1 & 3 & 5 \\
End of Life Index & 1.66 & 1.26 & 0 & 2 & 4 \\
Impatience index & -0.01 & 1.50 & -2.62 & -0.01 & 3.38 \\
Age Received SocSec & 63.40 & 2.03 & 60 & 62.8 & 73.1 \\
Act-Expected SocSec Claim Age & -0.19 & 2.46 & -14 & 0.1 & 9.1 \\
Age & 79.03 & 5.69 & 71 & 78 & 99 \\
Male & 0.38 & 0.48 & 0 & 0 & 1 \\
White & 0.84 & 0.36 & 0 & 1 & 1 \\
Hispanic & 0.10 & 0.30 & 0 & 0 & 1 \\
Education years & 12.37 & 3.25 & 0 & 12 & 17 \\
Married & 0.47 & 0.50 & 0 & 0 & 1 \\
Cognition score & 21.39 & 4.60 & 7 & 22 & 34 \\
Christian & 0.93 & 0.25 & 0 & 1 & 1 \\
Jewish & 0.02 & 0.13 & 0 & 0 & 1 \\
Procrastinator score & 4.75 & 3.44 & 0 & 5 & 10 \\
Optimistic live to 85+ & 0.54 & 0.50 & 0 & 1 & 1 \\
Have any cancer & 0.25 & 0.43 & 0 & 0 & 1 \\
Have lung disease & 0.13 & 0.34 & 0 & 0 & 1 \\
Have heart condition & 0.36 & 0.48 & 0 & 0 & 1 \\
Have stroke & 0.12 & 0.32 & 0 & 0 & 1 \\
Mental shortfall & 0.02 & 0.12 & 0 & 0 & 1 \\
HH income (\$) & 44,618 & 63,219 & 0 & 28,372 & 677,645 \\
\hline & & & & &
\end{tabular}




\section{Online Appendix A. HRS Time Discounting Module}

Asked only of nonproxy respondents older than age 70

V051_GIVEUP: FUTURE ORIENTED-- 0 TO 10 (HIGH)

First, how do you see yourself -- are you a person who is generally willing to give up something today in order to benefit from that in the future, or are you not willing to do so? Please use a scale from 0 to 10, where 0 means you are "completely unwilling to give up something today" and a 10 means you are "very willing to give up something today". Use the values in-between to indicate where you fall on the scale.

Scale range 0-10:

98. DK

99. RF

\section{V052_INTRO: INTRODUCTION TO PAYMENT CHOICES}

Now, suppose you were given the choice between receiving a payment today or a payment in 12 months. We will now present to you 5 situations. The payment today is the same in each of these situations. The payment in 12 months differs in every situation. For each of these situations, we would like to know which you would choose.

V053_100-154: 100 DOLLARS OR 154 DOLLARS

Would you rather receive 100 Dollars today or 154 Dollars in 12 months?

1. TODAY $\rightarrow$ GO TO V069

2. IN 12 MONTHS

8. DK

9. RF

V054_100-125: 100 DOLLARS OR 125 DOLLARS

Would you rather receive 100 Dollars today or 125 Dollars in 12 months?

1. TODAY

$\square$ GO TO V062

2. IN 12 MONTHS

8. DK

9. RF

V055_100-112: 100 DOLLARS OR 112 DOLLARS

Would you rather receive 100 Dollars today or 112 Dollars in 12 months?

1. TODAY $\rightarrow$ GO TO V059

2. IN 12 MONTHS

8. DK

9. $\mathrm{RF}$

V056_100-106: 100 DOLLARS OR 106 DOLLARS

Would you rather receive 100 Dollars today or 106 Dollars in 12 months?

1. TODAY $\rightarrow$ GO TO V058

2. IN 12 MONTHS

8. DK

9. RF 
V057_100-103: 100 DOLLARS OR 103 DOLLARS

Would you rather receive 100 Dollars today or 103 Dollars in 12 months?

1. TODAY

2. IN 12 MONTHS

8. DK

9. RF GO TO V084

V058_100-109: 100 DOLLARS OR 109 DOLLARS

Would you rather receive 100 Dollars today or 109 Dollars in 12 months?

1. TODAY

2. IN 12 MONTHS

8. DK

9. RF GO TO V084-

V059 100-119: 100 DOLLARS OR 119 DOLLARS

Would you rather receive 100 Dollars today or 119 Dollars in 12 months?

1. TODAY

2. IN 12 MONTHS $\rightarrow$ GO TO V061

8. DK

9. RF

V060 100-122: 100 DOLLARS OR 122 DOLLARS

Would you rather receive 100 Dollars today or 122 Dollars in 12 months?

1. TODAY

2. IN 12 MONTHS

8. DK

9. $\mathrm{RF}$ GO TO V084

V061_100-116: 100 DOLLARS OR 116 DOLLARS

Would you rather receive 100 Dollars today or 116 Dollars in 12 months?

1. TODAY

2. IN 12 MONTHS

8. DK

9. RF GO TO V084

V062_100-139: 100 DOLLARS OR 139 DOLLARS

Would you rather receive 100 Dollars today or 139 Dollars in 12 months?

1. TODAY $\rightarrow$ GO TO V066

2. IN 12 MONTHS

8. DK

9. RF

V063_100-132: 100 DOLLARS OR 132 DOLLARS

Would you rather receive 100 Dollars today or 132 Dollars in 12 months?

1. TODAY $\rightarrow$ GO TO V065 
2. IN 12 MONTHS

8. DK

9. RF

V064_100-129: 100 DOLLARS OR 129 DOLLARS

Would you rather receive 100 Dollars today or 129 Dollars in 12 months?

1. TODAY

2. IN 12 MONTHS

8. DK

9. $\mathrm{RF}$ GO TO V084

V065_100-136: 100 DOLLARS OR 136 DOLLARS

Would you rather receive 100 Dollars today or 136 Dollars in 12 months?

1. TODAY

2. IN 12 MONTHS

8. DK

9. RF GO TO V084

V066_100-146: 100 DOLLARS OR 146 DOLLARS

Would you rather receive 100 Dollars today or 146 Dollars in 12 months?

1. TODAY $\rightarrow$ GO TO V068

2. IN 12 MONTHS

8. DK

9. RF

V067_100-143: 100 DOLLARS OR 143 DOLLARS

Would you rather receive 100 Dollars today or 143 Dollars in 12 months?

1. TODAY

2. IN 12 MONTHS

8. DK

9. $\mathrm{RF}$

V068_100-150: 100 DOLLARS OR 150 DOLLARS

Would you rather receive 100 Dollars today or 150 Dollars in 12 months?

1. TODAY

2. IN 12 MONTHS

8. DK

9. RF GO TO V084 -

V069_100-185: 100 DOLLARS OR 185 DOLLARS

Would you rather receive 100 Dollars today or 185 Dollars in 12 months?

1. TODAY

2. IN 12 MONTHS $\rightarrow$ GO TO V077

8. DK

9. $\mathrm{RF}$ 
V070_100-202: 100 DOLLARS OR 202 DOLLARS

Would you rather receive 100 Dollars today or 202 Dollars in 12 months?

1. TODAY $\rightarrow$ GO TO V074

2. IN 12 MONTHS

8. DK

9. RF

V071_100-193: 100 DOLLARS OR 193 DOLLARS

Would you rather receive 100 Dollars today or 193 Dollars in 12 months?

1. TODAY

2. IN 12 MONTHS $\rightarrow$ GO TO V073

8. DK

9. RF

V072_100-197: 100 DOLLARS OR 197 DOLLARS

Would you rather receive 100 Dollars today or 197 Dollars in 12 months?

1. TODAY

2. IN 12 MONTHS

8. DK

9. $\mathrm{RF}$

-------------- GO TO V084

V073_100-189

100 DOLLARS OR 189 DOLLARS

Would you rather receive 100 Dollars today or 189 Dollars in 12 months?

1. TODAY

2. IN 12 MONTHS

8. DK

9. $\mathrm{RF}$ GO TO V084

V074_100-210: 100 DOLLARS OR 210 DOLLARS

Would you rather receive 100 Dollars today or 210 Dollars in 12 months?

1. TODAY

2. IN 12 MONTHS $\rightarrow$ GO TO V076

8. DK

9. RF

V075_100-215: 100 DOLLARS OR 215 DOLLARS

Would you rather receive 100 Dollars today or 215 Dollars in 12 months?

1. TODAY

2. IN 12 MONTHS

8. DK

9. $\mathrm{RF}$

V076_100-206: 100 DOLLARS OR 206 DOLLARS

Would you rather receive 100 Dollars today or 206 Dollars in 12 months?

1. TODAY 
2. IN 12 MONTHS

8. DK

9. RF GO TO V084

V077_100-169: 100 DOLLARS OR 169 DOLLARS

Would you rather receive 100 Dollars today or 169 Dollars in 12 months?

1. TODAY $\rightarrow$ GO TO V081

2. IN 12 MONTHS

8. DK

9. $\mathrm{RF}$

V078_100-161: 100 DOLLARS OR 161 DOLLARS

Would you rather receive 100 Dollars today or 161 Dollars in 12 months?

1. TODAY $\rightarrow$ GO TO V080

2. IN 12 MONTHS

8. DK

9. $\mathrm{RF}$

V079_100-158: 100 DOLLARS OR 158 DOLLARS

Would you rather receive 100 Dollars today or 158 Dollars in 12 months?

1. TODAY

2. IN 12 MONTHS

8. DK

9. $\mathrm{RF}$

V080_100-165: 100 DOLLARS OR 165 DOLLARS

Would you rather receive 100 Dollars today or 165 Dollars in 12 months?

1. TODAY

2. IN 12 MONTHS

8. DK

9. RF GO TO V084 -

V081_100-177: 100 DOLLARS OR 177 DOLLARS

Would you rather receive 100 Dollars today or 177 Dollars in 12 months?

1. TODAY $\rightarrow$ GO TO V083

2. IN 12 MONTHS

8. DK

9. RF

V082_100-173: 100 DOLLARS OR 173 DOLLARS

Would you rather receive 100 Dollars today or 173 Dollars in 12 months?

1. TODAY

2. IN 12 MONTHS

8. DK

9. RF 
V083_100-181: 100 DOLLARS OR 181 DOLLARS

Would you rather receive 100 Dollars today or 181 Dollars in 12 months?

1. TODAY

2. IN 12 MONTHS

8. DK

9. RF

\section{ASK EVERYONE}

V084_POSTPONER: DO YOU POSTPONE 0 TO 10-HIGH

How well does the following statement describe you as a person? I tend to postpone things even though it would be better to get them done right away. Use a scale from 0 to 10 , where 0 means "does not describe me at all" and a 10 means "describes me perfectly". Use the values in-between to indicate where you fall on the scale.

Scale range 0-10:

98. DK

99. RF

\section{V085_LOTTERY: LOTTERY VS SURE PAYMENT AMOUNT}

IWER: Read slowly.

Please imagine that you have won a prize in a contest. Now you can choose between two different payment methods, either a lottery or a sure payment. If you choose the lottery there is a 50 percent chance that you would receive $\$ 1,000$, and an equally high chance that you would receive nothing. What is the smallest sure payment that would make you prefer the sure payment over playing the lottery?

Amount \$ (\$0-\$99997)

99998. DK

99999. RF 


\section{Online Appendix B. Generating Patience Scores and Internal Rates of Return Measures from Our Survey Module}

This document explains how we calculate Patience Scores and Internal Rates of Return (IRR) for all respondents in our data, using responses to the HRS module described above.

\section{Patience Scores}

Respondents' patience scores were elicited using the Survey Module (see Appendix A) and coding responses as follows, depending on the skip logic each person's answers traced.

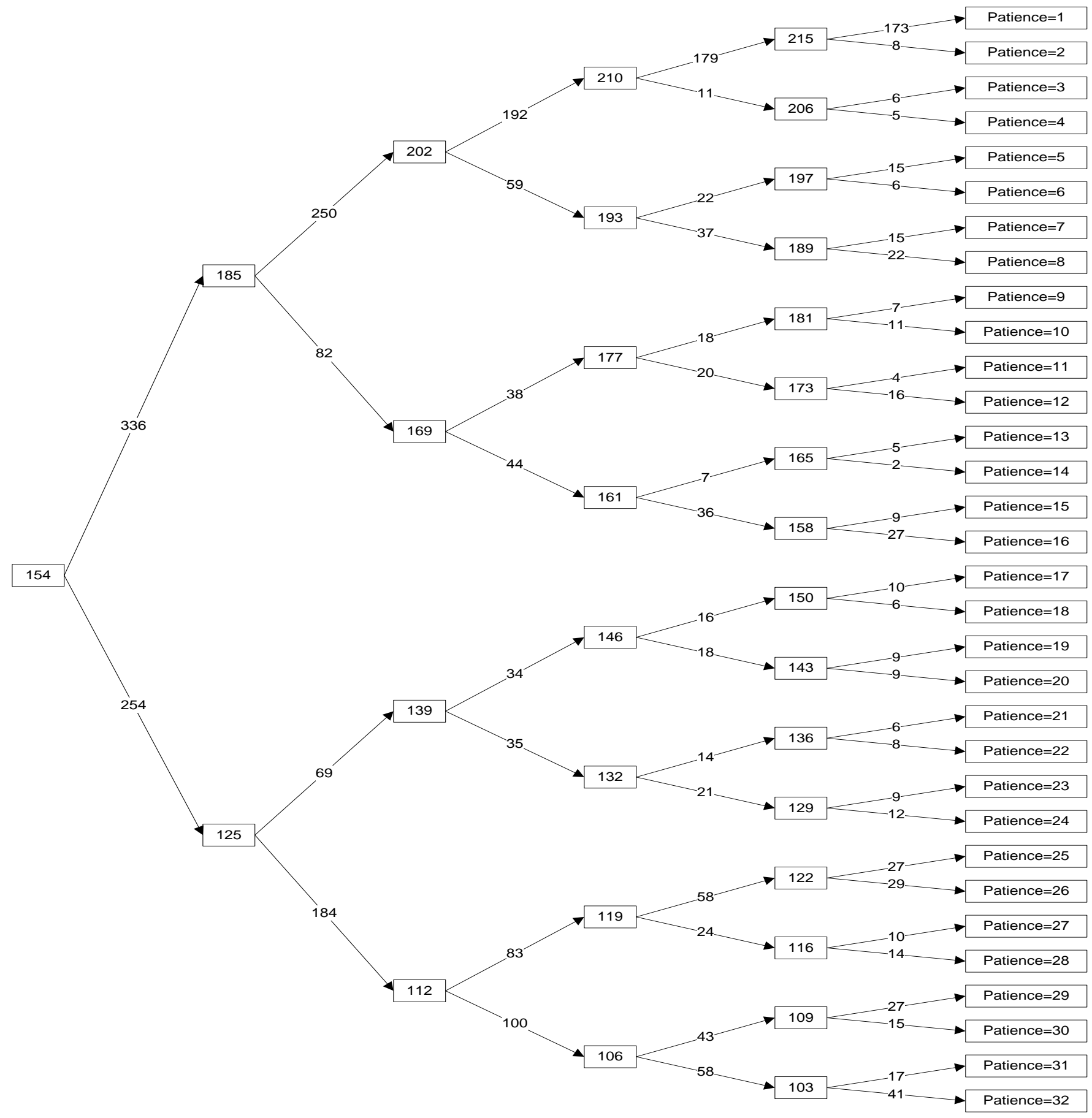




\section{How We Computed the IRRs}

The annual Internal Rate of Return (IRR) is the annual interest rate that makes it equally attractive to receive $\$ 100$ now, or a larger amount $\$ X$ in 12 months. If the interest rate is compounded once per year, the IRR satisfies this equation:

$(1+\mathrm{IRR}) * \$ 100=\$ X$

We can solve for the IRR as:

$\mathrm{IRR}=(\$ X / \$ 100)-1$

With compounding twice per year, the annual IRR satisfies:

$(1+\mathrm{IRR} / 2)^{\wedge} 2 * \$ 100=\$ \mathrm{X}$

$\operatorname{IRR}=2 *[[(\$ X / \$ 100) \wedge(.5)]-1]$

With continuous compounding, the annual IRR satisfies:

$\left(\mathrm{e}^{\wedge} \mathrm{IRR}\right) * \$ 100=\$ \mathrm{X}$

$\mathrm{IRR}=\ln ([(\$ X / \$ 100)$ 


\section{Inferring Respondents’ IRRs from Responses to Time Preference Questions:}

A respondent's choices in the time preference questions reveal something about the size of delayed payment $\$ Z$, received in 12 months that would make him willing to give up $\$ 100$ received now. We cannot infer his exact $\$ Z$, but we infer lower and upper bounds for his true $\$ Z$. This in turn allows us to infer bounds for an individual's IRR, i.e., the annual interest rate that solves $(1+\mathrm{IRR}) * \$ 100=\$ Z$ for that person. The patience score derived from the survey is given as follows:

\begin{tabular}{|c|c|}
\hline Patience score & Size of delayed payment \\
\hline 1 & $\$ Z>=\$ 215$ \\
\hline 2 & $\$ 215>=\$ Z>=\$ 210$ \\
\hline 3 & $\$ 210>=\$ Z>=\$ 206$ \\
\hline 4 & $\$ 206>=\$ Z>=\$ 202$ \\
\hline 5 & $\$ 2062>=\$ Z>=\$ 197$ \\
\hline 6 & $\$ 197>=\$ Z>=\$ 193$ \\
\hline 7 & $\$ 193>=\$ Z>=\$ 189$ \\
\hline 8 & $\$ 189>=\$ Z>=\$ 185$ \\
\hline 9 & $\$ 185>=\$ Z>=\$ 181$ \\
\hline 10 & $\$ 181>=\$ Z>=\$ 177$ \\
\hline 11 & $\$ 177>=\$ Z>=\$ 173$ \\
\hline 12 & $\$ 173>=\$ Z>=\$ 169$ \\
\hline 13 & $\$ 169>=\$ Z>=\$ 165$ \\
\hline 14 & $\$ 165>=\$ Z>=\$ 161$ \\
\hline 15 & $\$ 161>=\$ Z>=\$ 158$ \\
\hline 16 & $\$ 158>=\$ Z>=\$ 154$ \\
\hline 17 & $\$ 154>=\$ Z>=\$ 150$ \\
\hline 18 & $\$ 150>=\$ Z>=\$ 146$ \\
\hline 19 & $\$ 146>=\$ Z>=\$ 143$ \\
\hline 20 & $\$ 143>=\$ Z>=\$ 139$ \\
\hline 21 & $\$ 139>=\$ Z>=\$ 136$ \\
\hline 22 & $\$ 136>=\$ Z>=\$ 132$ \\
\hline 23 & $\$ 132>=\$ Z>=\$ 129$ \\
\hline 24 & $\$ 129>=\$ Z>=\$ 125$ \\
\hline 25 & $\$ 125>=\$ Z>=\$ 122$ \\
\hline 26 & $\$ 122>=\$ Z>=\$ 119$ \\
\hline 27 & $\$ 119>=\$ Z>=\$ 116$ \\
\hline 28 & $\$ 116>=\$ Z>=\$ 112$ \\
\hline 29 & $\$ 112>=\$ Z>=\$ 109$ \\
\hline 30 & $\$ 109>=\$ Z>=\$ 106$ \\
\hline 31 & $\$ 106>=\$ Z>=\$ 103$ \\
\hline 32 & $\$ 103>=\$ Z>=\$ 0$ \\
\hline
\end{tabular}

For example, suppose someone has a patience score of 25. In this case we know:

$\$ 125>=\$ Z>=\$ 122$. Thus, $\$ Z$ is at least $\$ 122$ and at most $\$ 125$.

If we compounding occurred once per year, this means the person's lower bound IRR is:

IRRlower $=(\$ 122 / \$ 100)-1=0.22$. And the upper bound IRR is: IRRupper $=(\$ 125 / \$ 100)-1=$ 0.25 . We take the midpoint to be the respondent's IRR: IRR $=(.22+.25) / 2=0.235$. In the case of patience score of 1, we only have the lower bound, so we just use the lower bound. 
The next table shows computed IRRs given three frequencies of compounding:

Summary of IRRs as a function of Patience Score and Frequency of Compounding

\begin{tabular}{cccc}
\hline $\begin{array}{c}\text { Patience } \\
\text { score }\end{array}$ & $\begin{array}{c}\text { Annual } \\
\text { compounding }\end{array}$ & $\begin{array}{c}\text { Semi-annual } \\
\text { compounding }\end{array}$ & $\begin{array}{c}\text { Continuous } \\
\text { compounding }\end{array}$ \\
\hline 32 & 0.03 & 0.03 & 0.03 \\
31 & 0.05 & 0.04 & 0.04 \\
30 & 0.08 & 0.07 & 0.07 \\
29 & 0.11 & 0.10 & 0.10 \\
28 & 0.14 & 0.14 & 0.13 \\
27 & 0.18 & 0.17 & 0.16 \\
26 & 0.21 & 0.20 & 0.19 \\
25 & 0.24 & 0.22 & 0.21 \\
24 & 0.27 & 0.25 & 0.24 \\
23 & 0.31 & 0.28 & 0.27 \\
22 & 0.34 & 0.32 & 0.29 \\
21 & 0.38 & 0.35 & 0.32 \\
20 & 0.41 & 0.37 & 0.34 \\
19 & 0.45 & 0.40 & 0.37 \\
18 & 0.48 & 0.43 & 0.39 \\
17 & 0.52 & 0.47 & 0.42 \\
16 & 0.56 & 0.50 & 0.44 \\
15 & 0.60 & 0.53 & 0.47 \\
14 & 0.63 & 0.55 & 0.49 \\
13 & 0.67 & 0.58 & 0.51 \\
12 & 0.71 & 0.62 & 0.54 \\
11 & 0.75 & 0.65 & 0.56 \\
10 & 0.79 & 0.68 & 0.58 \\
9 & 0.83 & 0.71 & 0.60 \\
8 & 0.87 & 0.73 & 0.63 \\
7 & 0.91 & 0.76 & 0.65 \\
6 & 0.95 & 0.79 & 0.67 \\
5 & 1.00 & 0.82 & 0.69 \\
4 & 1.04 & 0.86 & 0.71 \\
3 & 1.08 & 0.88 & 0.73 \\
2 & 1.13 & 0.92 & 0.75 \\
1 & 1.15 & 0.93 & 0.77 \\
\hline & & &
\end{tabular}

